\title{
Alcohol Dependence Disrupts Amygdalar L-Type Voltage-Gated Calcium Channel Mechanisms
}

\author{
Florence P. Varodayan, @Giordano de Guglielmo, Marian L. Logrip, @olivier George, and Marisa Roberto \\ The Scripps Research Institute, Department of Neuroscience, La Jolla, California 92037
}

L-type voltage-gated calcium channels (LTCCs) are implicated in several psychiatric disorders that are comorbid with alcoholism and involve amygdala dysfunction. Within the amygdala, the central nucleus (CeA) is critical in acute alcohol's reinforcing actions, and its dysregulation in human alcoholics drives their negative emotional state and motivation to drink. Here we investigated the specific role of CeA LTCCs in the effects of acute alcohol at the molecular, cellular physiology, and behavioral levels, and their potential neuroadaptation in alcohol-dependent rats. Alcohol increases CeA activity (neuronal firing rates and GABA release) in naive rats by engaging LTCCs, and intra-CeA LTCC blockade reduces alcohol intake in nondependent rats. Alcohol dependence reduces CeA LTCC membrane abundance and disrupts this LTCC-based mechanism; instead, corticotropin-releasing factor type 1 receptors $\left(\mathrm{CRF}_{1} \mathrm{~s}\right)$ mediate alcohol's effects on $\mathrm{CeA}$ activity and drive the escalated alcohol intake of alcohol-dependent rats. Collectively, our data indicate that alcohol dependence functionally alters the molecular mechanisms underlying the CeA's response to alcohol (from LTCC- to CRF $_{1}$-driven). This mechanistic switch contributes to and reflects the prominent role of the $\mathrm{CeA}$ in the negative emotional state that drives excessive drinking.

Key words: alcohol/ethanol; central amygdala; corticotropin-releasing factor type 1 receptor (CRF1);GABA; L-type voltage-gated calcium channel (LTCC)

\section{Significance Statement}

The central amygdala (CeA) plays a critical role in the development of alcohol dependence. As a result, much preclinical alcohol research aims to identify relevant CeA neuroadaptions that promote the transition to dependence. Here we report that acute alcohol increases CeA neuronal activity in naive rats by engaging L-type calcium channels (LTCCs) and that intra-CeA LTCC blockade reduces alcohol intake in nondependent rats. Alcohol dependence disrupts this LTCC-based mechanism; instead, corticotropin-releasing factor type 1 receptors $\left(\mathrm{CRF}_{1} \mathrm{~s}\right)$ mediate alcohol's effects on CeA activity and drive the escalated alcohol intake of alcohol-dependent rats. This switch reflects the important role of the CeA in the pathophysiology of alcohol dependence and represents a new potential avenue for therapeutic intervention during the transition period.

\section{Introduction}

Amygdala dysregulation contributes to several human psychiatric disorders (Bhat et al., 2012), and is hypothesized to drive the transi-

Received Dec. 4, 2016; revised March 23, 2017; accepted March 24, 2017.

Author contributions: F.P.V., G.d.G., O.G., and M.R. designed research; F.P.V., G.d.G., and M.L.L. performed research; F.P.V., G.d.G., and M.L.L. analyzed data; F.P.V., O.G., and M.R. wrote the paper.

This work was supported by NIH Grants AA015566, AA021491, AA017447, AA006420, AA013498, AA020608, AA022977 and AA021802. We thank Dr. Matthew Buczynski, Maury Cole, Courtney Leiter, and Dr. Miranda Staples for their technical support; Drs. Floyd Bloom, Michal Bajo, Candice Contet, Sean Farris, Sophia Khom, Reesha Patel, and Igor Ponomarev for valuable comments on the paper; R121919 was synthesized by Dr. Kenner Rice at the National Institute on Drug Abuse, National Institutes of Health.

The authors declare no competing financial interests.

Correspondence should be addressed to Drs. Florence P. Varodayan and Marisa Roberto, Department of Neuroscience, The Scripps Research Institute, SP30-1150, 10550 N. Torrey Pines Road, La Jolla, CA 92037. E-mail: varodaya@scripps.edu and mroberto@scripps.edu.

M. L. Logrip's present address: Indiana University-Purdue University Indianapolis, Department of Psychology, Indianapolis, IN 46202.

DOI:10.1523/JNEUROSCI.3721-16.2017

Copyright $\odot 2017$ the authors $\quad 0270-6474 / 17 / 374593-11 \$ 15.00 / 0$ tion from social drinking to alcohol dependence (Koob and Volkow, 2010). Alcoholics display increased amygdala activity during cueelicited cravings and alcohol intoxication (Koob and Volkow, 2010), and increased amygdala-based perceptions of fear (Townshend and Duka, 2003). Within the amygdala, the central nucleus (CeA) is a hub for negative emotion, anxiety, and stress; its activation promotes escalated alcohol intake and anxiety-like behaviors in withdrawn rats (Koob and Volkow, 2010; Gilpin et al., 2015). These clinical and preclinical findings suggest that chronic alcohol-induced neuroadaptations in the CeA may contribute to the pathophysiology of alcohol use disorders.

Recently, L-type voltage-gated calcium channels (LTCCs) have been implicated in several amygdala-related psychiatric disorders that show high comorbidity with alcoholism, such as bipolar disease, schizophrenia, and major depression (Bhat et al., 2012). These channels are high voltage-activating with slow activation kinetics, and are critical for activity-dependent gene expression and regulating plasticity at certain synapses (Deisseroth 
et al., 2003; Lipscombe et al., 2004). LTCCs normally open too slowly to respond to single action potentials and are recruited under conditions that promote prolonged membrane depolarization (Lipscombe et al., 2004). The two major LTCC subtypes, $\mathrm{Ca}_{\mathrm{v}} 1.2$ and $\mathrm{Ca}_{\mathrm{v}} 1.3$, are expressed throughout the nervous system, but have different biophysical and subcellular distributions (Hell et al., 1993; Lipscombe et al., 2004; Sinnegger-Brauns et al., 2009). These channels preferentially localize to the soma and dendrites of neurons, and their contribution to action potential-dependent calcium entry in these regions is unclear. However, their activity can stimulate inositol trisphosphate receptors $\left(\mathrm{IP}_{3} \mathrm{Rs}\right)$ and ryanodine receptors (RyRs) to promote intracellular calcium release (Deisseroth et al., 2003).

Previous studies have identified a role for LTCCs in alcohol's cellular and behavioral effects. Acute alcohol modulates LTCC activity in vitro (Walter and Messing, 1999), whereas in vivo LTCC blockade reduced rodent alcohol consumption (De Beun et al., 1996; Walter and Messing, 1999), alcohol withdrawal symptoms (Walter and Messing, 1999; Watson and Little, 2002), and cue-induced alcohol reinstatement (Uhrig et al., 2017). There have been a few human alcohol-related clinical trials with LTCC blockers and modulators, but the effects on alcohol intake, withdrawal, and abstinence were conflicting (Altamura et al., 1990; Banger et al., 1992; Rush and Pazzaglia, 1998; Mason et al., 2014). Notably, gabapentin, which binds the $\alpha_{2} \delta$ subunit of LTCCs (and other voltage-gated calcium channels; Sills, 2006) and suppresses CeA activity (Roberto et al., 2008), increased abstinence in human alcoholics (Mason et al., 2014). It is therefore critical to further investigate the neurobiological mechanisms linking LTCCs to alcohol drinking behaviors.

The CeA is an integrative hub that mediates negative emotional responses to fearful and anxiety-inducing stimuli (Gilpin et al., 2015). CeA activity is central to alcohol's reinforcing actions, and its overactivation is a hallmark of the transition to dependence (Koob and Volkow, 2010; Gilpin et al., 2015). The CeA is largely (95\%) inhibitory, with an extensively interconnected network of GABA interneurons and GABA projection neurons (Lopez de Armentia and Sah, 2004; Haubensak et al., 2010; Marek et al., 2013), and we have previously shown that acute alcohol increases GABA release similarly in the CeA of naive and alcohol-dependent rats (Roberto et al., 2004; Herman et al., 2013b; Herman and Roberto, 2016). Alcohol-dependent rats also have increased basal levels of CeA GABA release (Roberto et al., 2004; Herman et al., 2013b) and increased CeA sensitivity to stress peptides [particularly corticotropin-releasing factor (CRF); Roberto et al., 2010; Gilpin et al., 2015]. Here we investigated the specific role of LTCCs in alcohol's actions in the CeA at the molecular, cellular physiology, and behavioral levels, and their potential neuroadaptation with alcohol dependence.

\section{Materials and Methods}

All procedures were approved by The Scripps Research Institute Institutional Animal Care and Use Committee and were consistent with the National Institutes of Health Guide for the Care and Use of Laboratory Animals.

Chronic intermittent ethanol exposure. Adult male Sprague-Dawley rats ( $n=140 ; 345.8 \pm 6.1 \mathrm{~g}$ ) were obtained from Charles River Laboratories. Chronic intermittent ethanol (CIE) rats $(n=44)$ received $5-7$ weeks of daily ethanol vapor ( $14 \mathrm{~h}$ vapor $/ 10 \mathrm{~h}$ air). This method consistently produces physical ethanol dependence in rats, as exhibited by their increased ethanol drinking behavior, anxiety-like behavior, and reward deficits (O'Dell et al., 2004; Gilpin et al., 2008; Roberto et al., 2010). Blood alcohol levels (BALs) were measured 1-2 times/week by tail-bleeding and upon euthanasia. The mean BAL was $180 \pm 6 \mathrm{mg} / \mathrm{dl}$. Naive rats $(n=96)$ were treated similarly, except with continuous air exposure. CIE rats were euthanized 15-30 min before the end of daily vapor exposure for molecular biology tissue collection or electrophysiology slice preparation in ethanol-free solutions. Thus, the electrophysiology recordings were performed in brain slices undergoing acute in vitro withdrawal $(1-8 \mathrm{~h})$.

Electrophysiology. Rats were anesthetized with 3-5\% isoflurane and decapitated, as previously described (Roberto et al., 2010; Herman et al., 2013b; Herman and Roberto, 2016; Varodayan et al., 2016). The brains were placed in oxygenated $\left(95 \% \mathrm{O}_{2} / 5 \% \mathrm{CO}_{2}\right)$, cold high-sucrose solution, $\mathrm{pH} 7.3-7.4$, containing the following (in $\mathrm{mm}$ ): 206.0 sucrose, 2.5 $\mathrm{KCl}, 0.5 \mathrm{CaCl}_{2}, 7.0 \mathrm{MgCl}_{2}, 1.2 \mathrm{NaH}_{2} \mathrm{PO}_{4}, 26.0 \mathrm{NaHCO}_{3}, 5.0$ glucose, and 5.0 HEPES. Coronal brain slices $(300 \mu \mathrm{m})$ were incubated in oxygenated artificial CSF (aCSF) containing the following (in $\mathrm{mm}$ ): $130.0 \mathrm{NaCl}, 3.5$ $\mathrm{KCl}, 2.0 \mathrm{CaCl}_{2}, 1.25 \mathrm{NaH}_{2} \mathrm{PO}_{4}, 1.5 \mathrm{MgSO}_{4}, 24.0 \mathrm{NaHCO}_{3}$, and 10.0 glucose for $30 \mathrm{~min}$ at $37^{\circ} \mathrm{C}$ and then $30 \mathrm{~min}$ at room temperature.

We recorded from 324 medial CeA neurons, visualized with infrared differential interference contrast optics, a $60 \times$ water-immersion objective (Olympus BX51WI), and a CCD camera (EXi Aqua, QImaging). Whole-cell voltage-clamp and cell-attached current-clamp recordings were performed in gap-free acquisition mode with a sampling rate per signal of $10 \mathrm{kHz}$ and low-pass filtered at $10 \mathrm{kHz}$, using a MultiClamp 700B amplifier, Digidata 1440A, and pClamp 10 software (Molecular Devices).

For the voltage-clamp recordings, pipettes (3-7 M 2 ; King Precision) were filled with internal solution containing the following (in $\mathrm{mM}$ ): 145.0 $\mathrm{KCl}$, 5.0 EGTA, 5.0 $\mathrm{MgCl}_{2}, 10.0$ HEPES, $2.0 \mathrm{Na}^{+}$-ATP, and $0.2 \mathrm{Na}^{+}$-GTP. Spontaneous $\mathrm{GABA}_{\mathrm{A}}$-mediated inhibitory postsynaptic currents (sIPSCs) were isolated with 6,7-dinitroquinoxaline-2,3-dione (DNQX; $20 \mu \mathrm{M}$ ), DL2-amino-5-phosphonovalerate (AP-5, $30 \mu \mathrm{M})$, and CGP 55845A (1 $\mu \mathrm{M})$. Neurons were clamped at $-60 \mathrm{mV}$ and experiments with a series resistance $>15 \mathrm{M} \Omega$ or a $>20 \%$ change in series resistance, as monitored with a $10 \mathrm{mV}$ pulse, were excluded. For experiments where the aCSF calcium concentration was altered, magnesium levels were also adjusted to compensate. For the current-clamp recordings, pipettes were filled with aCSF so as not to artificially disturb the ionic balance of the neuronal membrane (Alcami et al., 2012), and the firing rate was measured in the presence of DNQX, AP-5, and CGP 55845A. A second set of current-clamp recordings were conducted in the presence of the $\mathrm{GABA}_{\mathrm{A}}$ receptor antagonist bicuculline $(30 \mu \mathrm{M})$, as well as DNQX, AP-5, and CGP55845A.

For the voltage-clamp experiments, sIPSC frequency, amplitude, and kinetics were analyzed using Mini Analysis (Synaptosoft) and visually confirmed. Only sIPSCs $>5 \mathrm{pA}$ were accepted for analysis, and average sIPSC characteristics were based on 2-5 min of recording and a minimum of 60 events. For cell-attached experiments, the event frequency, with a minimum of 60 events, was analyzed using pClamp and visually confirmed. To control for cell-to-cell variation in baseline electrophysiology properties, drug effects were normalized to their own neuron's baseline (presented as control) before group analyses. All final values were analyzed for independent significance using one-sample $t$ tests and compared using two-tailed $t$ tests or two-way ANOVA with Bonferroni post hoc analyses, using Prism 5.02 (GraphPad). Data are presented as mean \pm SEM, with the number of cells and animals used for each experiment reported in the figure legend.

Drugs. We purchased $\omega$-agatoxin TK, 2-aminoethoxydiphenylborane (2APB), AP-5, CGP 55845A, DNQX, Ro 32-0432, ryanodine, and verapamil hydrochloride from Tocris Bioscience; 1,2-bis(2-aminophenoxy)ethane$N, N, N^{\prime}, N^{\prime}$-tetra-acetic acid (BAPTA), bicuculline, nifedipine, and RpcAMP from Sigma-Aldrich; $\omega$-conotoxin GVIA from AnaSpec; and alcohol from Remet. R121919 was synthesized by Dr. Kenner Rice at the Drug Design and Synthesis Section, Chemical Biology Research Branch, National Institute on Drug Abuse, National Institutes of Health, Bethesda, MD. Drugs were dissolved in aCSF and applied locally by Y-tubing (Murase et al., 1989) or bath perfusion.

Protein expression. Rats were anesthetized with isoflurane and decapitated. Coronal slices ( $2 \mathrm{~mm}$ thick) of naive and CIE rat brains $(n=6$ per group) were prepared with a wire matrix and $\mathrm{CeA}$ and control-region [medial prefrontal cortex (mPFC)] tissue were punched on a chilled stage with an 18 -gauge blunt needle and stored at $-80^{\circ} \mathrm{C}$. Samples were homogenized in $250 \mu \mathrm{l}$ buffer A containing the following (in $\mathrm{mm}$ ): 4.0 
HEPES, pH 7; 320.0 sucrose; 5.0 EDTA, pH 8; phosphatase inhibitor cocktail (PhosSTOP; Roche Life Science); and protease inhibitor cocktail (cOmplete, EDTA-free; Roche); using a rotor-stator homogenizer (Tissue Tearor, Cole-Parmer Instrument). The homogenate was enriched for membrane proteins as previously reported (Goebel-Goody et al., 2009), with slight modifications. Specifically, the homogenate was centrifuged $\left(1000 \times g, 10 \mathrm{~min}, 4^{\circ} \mathrm{C}\right)$ and supernatant collected. The pellet was resuspended in $250 \mu \mathrm{l}$ buffer $\mathrm{A}$, re-homogenized, re-centrifuged $(1000 \times \mathrm{g}, 10$ $\min , 4^{\circ} \mathrm{C}$ ), and the supernatant combined with the previously collected supernatant. Total supernatant was centrifuged $\left(100,000 \times g, 1 \mathrm{~h}, 4^{\circ} \mathrm{C}\right)$ and the pellet resuspended in $50 \mu \mathrm{l}$ buffer A. Samples $(25 \mu \mathrm{g})$ were loaded onto a 7.5\% SDS PAGE (Mini-PROTEAN TGX, Bio-Rad Laboratories), electrophoresed ( $100 \mathrm{~V}, 2 \mathrm{~h})$, and transferred to a PVDF membrane (100 mA, $22 \mathrm{~h}, 4^{\circ} \mathrm{C}$; Immobilon-P, EMD Millipore). Membranes were washed in Tris-buffered saline with $0.1 \%$ Tween 20 (TBST; SigmaAldrich), blocked in 5\% milk/TBST ( $2 \mathrm{~h}$, room temperature), incubated in primary antibody (overnight, $4^{\circ} \mathrm{C} ; \mathrm{Ca}_{\mathrm{v}} 1.2,240 \mathrm{kDa}, 1: 500$, Alomone Labs, ACC-003;) and incubated in HRP-conjugated secondary antibody ( $1 \mathrm{~h}$, room temperature; donkey anti-rabbit, 1:5000, EMD Millipore, AP182PMI). Proteins were visualized using enhanced chemiluminescence (SuperSignal West Pico, Thermo Scientific Pierce) and exposed to Hy-Blot CL film (Denville Scientific). To obtain a loading control, membranes were incubated with $0.4 \%$ Coomassie stain (in 50\% methanol, $10 \%$ acetic acid, $40 \% \mathrm{ddH}_{2} \mathrm{O}$; Coomassie Brilliant Blue R-250, Bio-Rad) for $15 \mathrm{~min}$ at room temperature, de-stained $\left(50 \% \mathrm{ddH}_{2} \mathrm{O}, 43 \%\right.$ methanol, 7\% acetic acid) and dried (Lee et al., 2015). Digital images were acquired using light transmission (film) or reflective (membrane) scanning on a Scanjet G4050 (Hewlett-Packard). Protein band optical densities (ODs) and Coomassie staining were measured using Image Studio Lite (Li-Cor Biosciences). To control for protein loading variation, each protein OD was normalized to its own lane's Coomassie staining (50$150 \mathrm{kDa}$; Welinder and Ekblad, 2011), and to control for membrane differences, the normalized protein value was then normalized to the mean value of all naive rat normalized values on the membrane. All final values were compared using two-tailed $t$ tests using Prism 5.02. Data are presented as mean \pm SEM.

Alcohol self-administration. Adult male Wistar rats (Charles River Laboratories), weighing 225-275 g at the beginning of the experiments, were housed two per cage in a temperature-controlled $\left(22^{\circ} \mathrm{C}\right)$ vivarium on a $12 \mathrm{~h} \mathrm{light/dark} \mathrm{cycle} \mathrm{(lights} \mathrm{on} \mathrm{at} \mathrm{8:00} \mathrm{P.M.)} \mathrm{with} \mathrm{ad} \mathrm{libitum} \mathrm{access} \mathrm{to} \mathrm{food}$ and water. All behavioral tests were conducted during the dark phase of the light/dark cycle.

Self-administration sessions were conducted in standard operant conditioning chambers (Med Associates). Animals were first trained to selfadminister 10\% (weight/volume) alcohol and water solutions on an FR1 schedule of reinforcement (i.e., each operant response was reinforced with $0.1 \mathrm{ml}$ of the solution), until a stable response was maintained. The rats were then made dependent by chronic intermittent exposure to alcohol vapors as previously described (O’Dell et al., 2004; Gilpin et al., 2008; de Guglielmo et al., 2016). They underwent cycles of $14 \mathrm{~h}$ on (BALs during vapor exposure ranged between 150 and $250 \mathrm{mg} / \mathrm{dl}$ ) and $10 \mathrm{~h}$ off, during which behavioral testing for operant self-administration occurred (FR1 schedule of reinforcement for 30 min sessions 3 times per week). In this model, rats exhibit somatic withdrawal signs and negative emotional symptoms reflected by anxiety-like responses and elevated brain reward thresholds (Schulteis et al., 1995; Roberts et al., 2000; Valdez et al., 2002; Rimondini et al., 2003; O'Dell et al., 2004; Sommer et al., 2007; Zhao et al., 2007; Edwards et al., 2012). Nondependent rats were not exposed to alcohol vapor.

Intracranial surgery and microinjections. For intracranial surgery, the animals were anesthetized with isoflurane. To reach the CeA, guide cannulas were implanted bilaterally using the following coordinates with reference to bregma: anterior/posterior, $-2.6 \mathrm{~mm}$; medial/lateral, \pm 4.2 $\mathrm{mm}$; dorsal/ventral, $-6.1 \mathrm{~mm}$. Target coordinates were calculated from a stereotaxic atlas (Paxinos and Watson, 2007) such that cannula tips were aimed $2.0 \mathrm{~mm}$ above the CeA. Obturators were inserted between microinjections to maintain cannula patency. The animals were allowed to recover for 1 week after surgery. For the microinjections, an infusion volume of $0.50 \mu \mathrm{l}$ was delivered over $2 \mathrm{~min}$ by CMA/100 microinfusion pump (CMA Microdialysis) via $31 \mathrm{G}$ injectors that projected $2 \mathrm{~mm}$ beyond the tip of the cannulae. Injectors were left in place for $1 \mathrm{~min}$ following the infusion to facilitate diffusion and reduce backflow.

Drugs. Alcohol drinking solution $10 \%(\mathrm{w} / \mathrm{v})$ was prepared by dilution of $95 \%$ ethanol (w/v) in water. Nifedipine (Sigma-Aldrich) and R121919 (NIH-NIDA) for systemic administration were dissolved in a vehicle composed of 5\% DMSO, 5\% Emulphor and 90\% distilled water and injected intraperitoneally (i.p.) at the doses 7.5 and $15 \mathrm{mg} / \mathrm{kg} / 2 \mathrm{ml}$ (nifedipine) or 10 and $20 \mathrm{mg} / \mathrm{kg} / 2 \mathrm{ml}$ (R121919) $1 \mathrm{~h}$ before each test session. Nifedipine $(0.125 \mu \mathrm{g} / 0.5 \mu \mathrm{l})$ and R121919 $(0.15 \mu \mathrm{g} / 0.5 \mu \mathrm{l})$ for intra-CeA administration were dissolved in a vehicle composed of 5\% DMSO, $5 \%$ Emulphor and $90 \%$ distilled water and injected 15 min before each test session.

Effect of systemic nifedipine and R121919 on alcohol self-administration in nondependent and dependent rats. After a stable baseline of intake was established, rats $(n=10)$ were injected with nifedipine (7.5, and 15 $\mathrm{mg} / \mathrm{kg} / 2 \mathrm{ml}$, i.p.) according to a Latin square design.

Three days after completion of the experiment on nifedipine, daily alcohol self-administration sessions resumed until stable levels of intake were re-established. Animals were then tested for the effect of R121919 (10 and $20 \mathrm{mg} / \mathrm{kg} / 2 \mathrm{ml}$ ) on alcohol self-administration according to a second Latin square design.

A second group of rats $(n=12)$ was moved into the vapor chamber boxes at the end the self-administration training, and left undisturbed for 3 weeks. Blood samples were collected once a week to determine the BALs. After this phase, rats were tested for alcohol (and water) selfadministration on an FR1 schedule of reinforcement for 30 min sessions until escalation of intake was accomplished. At this point the treatment started and animals were injected with nifedipine $(7.5$ and $15 \mathrm{mg} / \mathrm{kg} / 2$ $\mathrm{ml}$, i.p.) according to a Latin square design. Three days after completion of the experiment on nifedipine, daily alcohol self-administration sessions resumed until stable levels of intake were re-established. Animals were then tested for the effect of R121919 (10 and $20 \mathrm{mg} / \mathrm{kg} / 2 \mathrm{ml}$ ) on alcohol self-administration according to a second Latin square design. A baseline alcohol self-administration session was performed between each test session in the Latin square designs.

Effect of intra-CeA nifedipine and R121919 on alcohol self-administration in nondependent and dependent rats. At the end of the treatment, the 10 nondependent and the 12 dependent rats from the experiments described above were left undisturbed for 1 week, and then implanted with intra-CeA cannulae. After 1 week of recovery from the surgery, animals went back to the self-administration chambers to restore the baseline of alcohol intake. At this point the treatment started and dependent and nondependent rats were treated with vehicle, nifedipine $(0.125 \mu \mathrm{g} / 0.5 \mu \mathrm{l})$, or R121919 $(0.15 \mu \mathrm{g} / 0.5$ $\mu \mathrm{l})$ according to a Latin square design. We used just a single Latin square for both treatments because the two drugs were soluble in the same vehicle and to reduce the numbers of intra-CeA injections to minimize the tissue damage. At the end of the Latin square brains were harvested for histological verification of the cannula placement. Histological verification of cannulae placements revealed three errors ( 2 nondependent and 1 dependent) and data from these rats was excluded (see Fig. 3C).

Statistical analysis. Data are presented as mean \pm SEM and were analyzed by one-way repeated-measures ANOVA, followed by Newman Keuls post hoc tests. Escalation data were analyzed by the Student's $t$ test.

\section{Results}

\section{Basal CeA activity is higher in CIE rats}

We first assessed the effects of CIE, which induces physical ethanol dependence (O'Dell et al., 2004; Roberto et al., 2010), on CeA GABAergic transmission by recording spontaneous $\mathrm{GABA}_{\mathrm{A}}$ mediated IPSCs (sIPSCs) that were pharmacologically isolated with glutamate and $\mathrm{GABA}_{\mathrm{B}}$ receptor antagonists. CIE rats had significantly $\left(t_{(128)}=3.45, p<0.001\right.$ by unpaired $t$ test) higher sIPSC neuronal frequencies $(1.26 \pm 0.17 \mathrm{~Hz})$ versus naive rats $(0.72 \pm 0.06 \mathrm{~Hz}$; Fig. $1 A, B)$, with no difference in amplitudes and kinetics. For these experiments, increased sIPSC frequencies reflect higher release probabilities, whereas altered amplitudes and kinetics denote changed receptor sensitivity (Otis et al., 1994). 
A

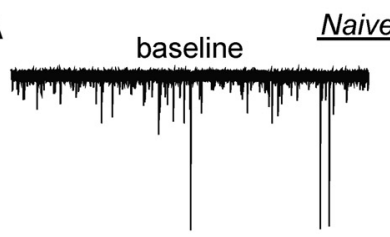

Naive Rat
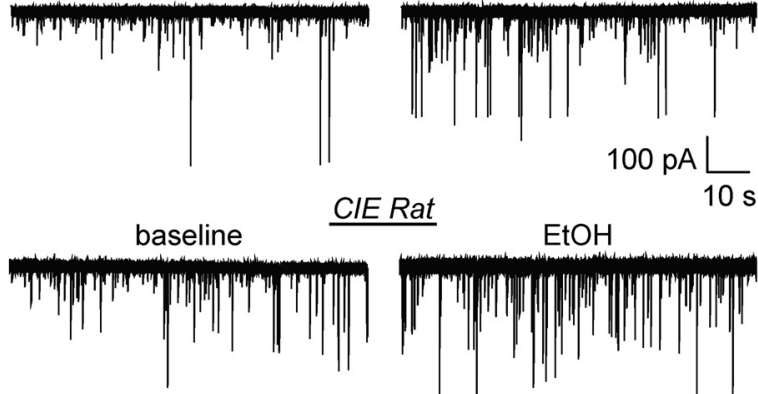

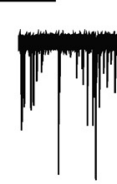
EtOH

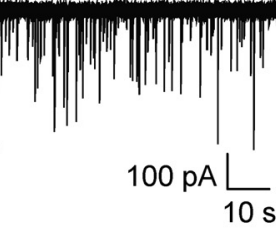

C

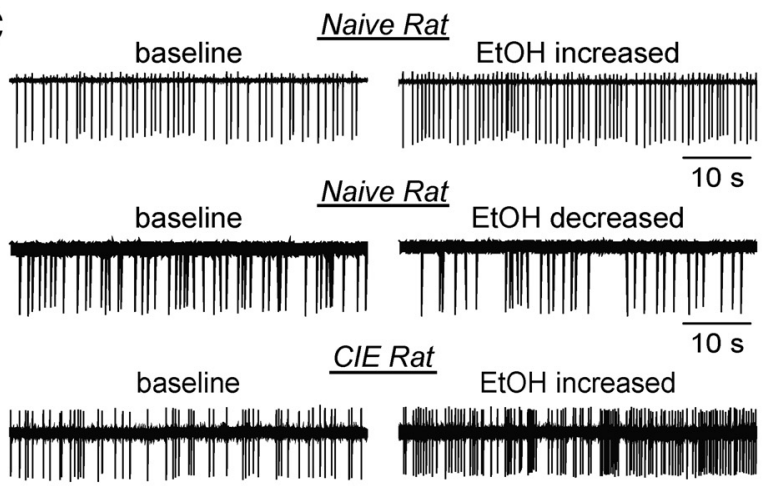

E

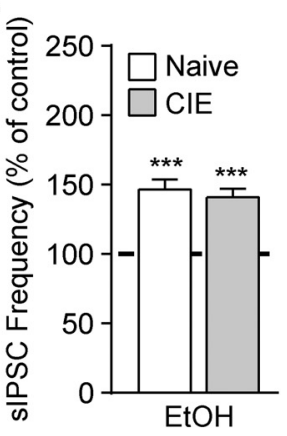

B

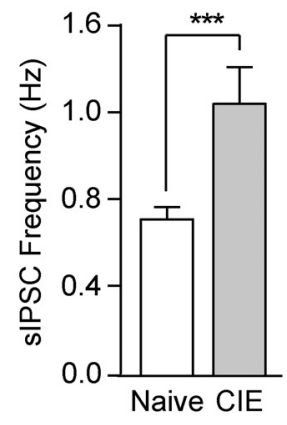

D

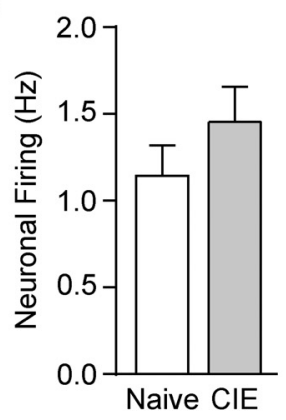

$F$

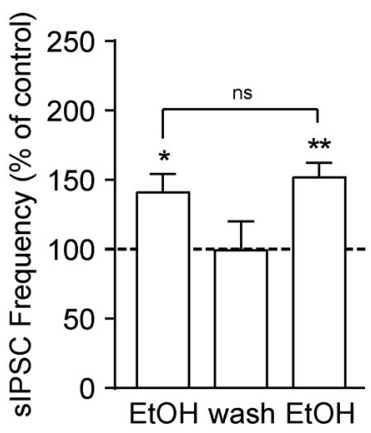

G

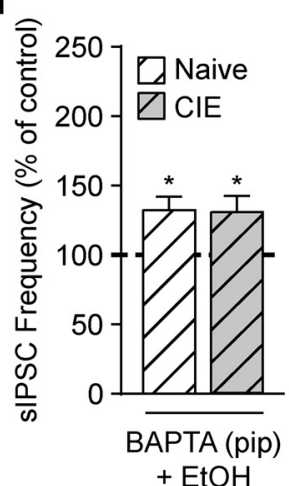

H

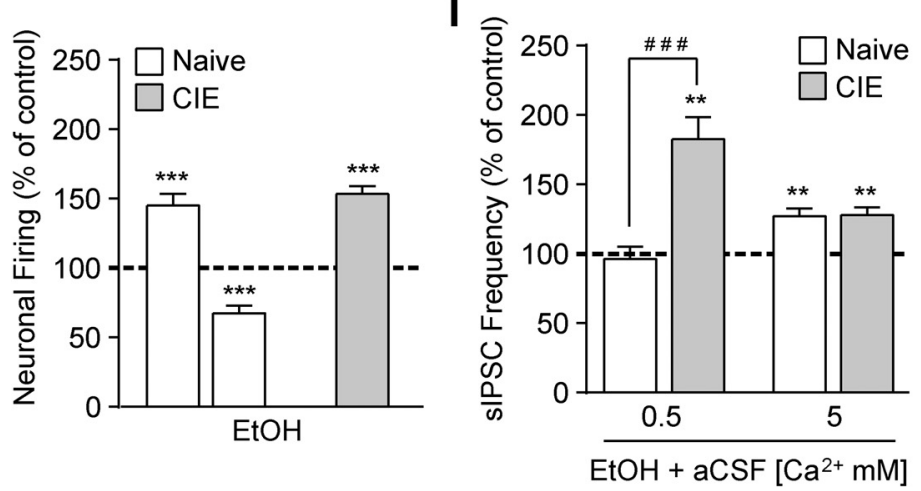

J

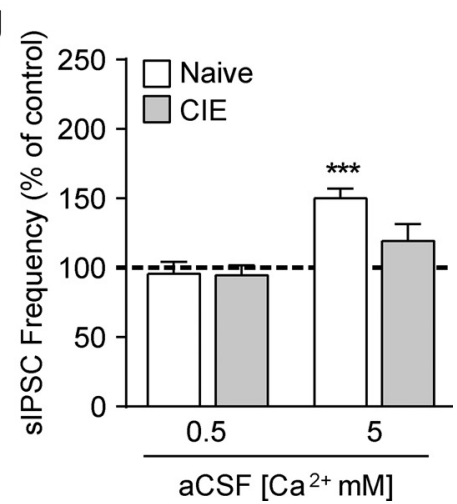

Figure 1. Alcohol dependence disrupted the role of extracellular calcium influx in acute alcohol-induced CeA activity. $A$, Representative sIPSC traces from CeA neurons of naive and CIE rats in baseline conditions and during acute alcohol ( $44 \mathrm{~mm}$ EtOH) superfusion. $B$, CIE rat CeA neurons ( 52 cells from 23 rats) have a higher baseline sIPSC frequency compared with naive rat cells ( 78 cells from 44 rats). $C$, Representative firing traces from CeA neurons of naive and (IE rats. $D$, The baseline firing rate was similar in cells from the CeA of naive (24 cells from 14 rats) and (IE rats (24 cells from 12 rats). $\boldsymbol{E}$, EtOH significantly increased sIPSC frequencies in naive (18 cells from 13 rats) and CIE CeA neurons ( 7 cells from 4 rats). $\boldsymbol{F}$, Cells treated twice with EtOH, with an intermediate 15 min wash period, showed no difference in EtOH enhancement of sIPSC frequency between the two applications ( 6 cells from 6 rats). G, EtOH significantly increased sIPSC frequencies in naive ( 8 cells from 5 rats) and CIE CeA neurons (8 cells from 4 rats) that were preloaded with $10 \mathrm{~mm}$ BAPTA. $\boldsymbol{H}$, In naive rats, EtOH significantly increased the firing rate in 16/24 (Figure legend continues.) 
Therefore, alcohol dependence increased CeA GABA release, without affecting $\mathrm{GABA}_{\mathrm{A}}$ receptor function.

To investigate whether this higher rate of GABA release in CIE rats stemmed from altered neuronal excitability, we performed cell-attached recordings in the presence of the same glutamate and $\mathrm{GABA}_{\mathrm{B}}$ receptor antagonists. Only a subset of CeA neurons displayed spontaneous firing and had a regular discharge pattern. In these cells, the firing rate was similar in naive $(1.14 \pm 0.18 \mathrm{~Hz})$ and CIE rats $(1.45 \pm 0.20 \mathrm{~Hz})$, indicating that alterations in firing rates do not drive the elevated GABA release observed in CIE rats (Fig. 1C,D).

\section{Alcohol increases CeA activity}

We next investigated acute alcohol's effects on CeA cellular physiology. A maximal dose of alcohol (44 mM EtOH; Roberto et al., 2004 ) increased the sIPSC frequency in cells from naive (146.6 \pm $7.3 \% ; t_{(17)}=6.42, p<0.001$ by one-sample $t$ test) and CIE rats $\left(141.0 \pm 6.3 \% ; t_{(6)}=6.53, p<0.001\right.$; Fig. $\left.1 E\right)$. Alcohol did not significantly alter the mean SIPSC amplitude or kinetics; however, it did increase sIPSC amplitudes in 3/18 naive and 1/7 CIE cells. Also, the sIPSC response did not change when alcohol was applied twice to the same neuron (EtOH exposure 1 vs exposure $2: t_{(5)}=0.78, p=0.47$ by paired two-tailed $t$ test; $t_{\mathrm{EtOH} 1(5)}=3.16$, $p<0.05$ by one sample $t$ test; $t_{\text {wash(5) }}=0.02, p=0.98$ by one sample $t$ test; $t_{\mathrm{EtOH} 2(5)}=5.04, p<0.01$ by one sample $t$ test), indicating the same lack of acute tolerance to alcohol as previously described (Fig. 1F; Roberto et al., 2004). To investigate the involvement of postsynaptic calcium in alcohol-induced GABA release, a calcium chelator (10 mM BAPTA) was added to the pipette internal solution. BAPTA (in the recording cell) had no effect on alcohol's potentiation of CeA neuronal sIPSC frequencies in both naive $\left(t_{(7)}=3.38, p<0.05\right.$ by one sample $t$ test $)$ and $\operatorname{CIE} \operatorname{rats}\left(t_{(7)}=2.71, p<0.05\right)$, suggesting that this effect does not require postsynaptic calcium (Fig. $1 G$ ).

As spontaneous GABAergic transmission is action potentialdependent, we also examined alcohol's effect on cellular firing in the presence of the same glutamate and $\mathrm{GABA}_{\mathrm{B}}$ receptor antagonists used to isolate the sIPSCs. In naive rats we found bidirectional changes (Herman and Roberto, 2016); alcohol increased the firing rate to $143.5 \pm 8.4 \%$ in $16 / 24$ naive rat CeA neu$\operatorname{rons}\left(t_{(15)}=5.19, p<0.001\right.$ by one sample $t$ test $)$ and decreased it to $67.4 \pm 5.5 \%$ in $8 / 24$ cells $\left(t_{(7)}=5.89, p<0.001\right.$; Fig. $\left.1 H\right)$. In CIE rats, alcohol increased the firing rate in $14 / 14$ cells (151.5 \pm $5.8 \% ; t_{(13)}=8.94, p<0.001$ by one sample $t$ test). To identify whether these alcohol-induced changes in firing were produced by alcohol's enhancement of local inhibitory transmission (i.e., increased sIPSC frequencies), a second set of cell-attached recordings were performed in naive rats using the $\mathrm{GABA}_{\mathrm{A}}$ receptor antagonist bicuculline (in addition to the glutamate and $\mathrm{GABA}_{\mathrm{B}}$ receptor antagonists used in Fig. $1 H$ ). In the absence of both GABA and glutamate synaptic transmission, alcohol still in-

(Figure legend continued.) cells and decreased it in $8 / 24$ cells (from 11 rats), whereas in CIE rats, EtOH increased the firing rate in $14 / 14$ cells from 8 rats. $I$, EtOH significantly increased the SIPSC frequencies in naive and CIE CeA neurons exposed to $5 \mathrm{~mm} \mathrm{Ca}^{2+} \mathrm{aCSF}$, and in CIE neurons exposed to $0.5 \mathrm{~mm} \mathrm{Ca}^{2+}$ aCSF (normalized to pre-EtOH baseline). For these extracellular calcium experiments, 5-8 cells from a minimum of 4 rats were used for each experimental group. $J$, The sIPSC frequency was increased only in naive rat CeA neurons bathed in $5 \mathrm{~mm} \mathrm{Ca}^{2+}$ aCSF (which is normalized to the $2 \mathrm{~mm} \mathrm{Ca}^{2+}$ aCSF baseline). Five to 13 cells from a minimum of 4 rats were used for each experimental group. All data are normalized to a pre-EtOH baseline (or $2 \mathrm{~mm}$ $\mathrm{Ca}^{2+} \mathrm{aCSF}$ baseline as specified) and presented as mean \pm SEM. ${ }^{*} p<0.05,{ }^{* *} p<0.01$, ${ }^{* * *} p<0.001 ;{ }^{\# \# \#} p<0.001$. Ns, not significant. creased the firing rate to $145.4 \pm 9.1 \%$ in $10 / 17$ naive rat CeA neurons $\left(t_{(9)}=5.00, p<0.001\right.$ by one sample $t$ test $)$ and decreased it to $63.6 \pm 7.9 \%$ in $7 / 17$ cells $\left(t_{(6)}=4.64, p<0.01\right.$; in total 17 cells from 5 rats), indicating that alcohol's effects on firing are not mediated by alcohol-induced neurotransmission.

\section{Calcium influx drives alcohol-induced CeA activity only in naive rats}

To investigate the role of extracellular calcium in alcohol's effects on sIPSCs, we altered the aCSF calcium concentration (from 2 to 0.5 or $5 \mathrm{mM}$ ). In naive rats, alcohol's potentiation of the neuronal sIPSC frequency was lost in the presence of $0.5 \mathrm{~mm}$ calcium aCSF $\left(t_{0.5 \mathrm{~mm}(5)}=0.42, p=0.69\right.$ by one sample $t$ test $t_{5 \mathrm{~mm}(7)}=4.90, p<$ 0.01 ), revealing a requirement for extracellular calcium influx (Fig. 1I). In contrast, alcohol increased the sIPSC frequency in CIE rat cells regardless of the extracellular calcium concentration $\left(t_{0.5 \mathrm{~mm}(4)}=5.25, p<0.01\right.$ by one sample $t$ test; $t_{5 \mathrm{~mm}(4)}=5.24, p<$ 0.01 ; Figure $1 I)$. Overall, when the effects of ethanol in all three aCSF conditions were compared $(2 \mathrm{~mm}$ aCSF data represented in Fig. $1 E$ ), there was a significant main effect of alcohol dependence $\left(F_{(1,43)}=11.80, p<0.01\right.$ by two-way ANOVA $)$ and a significant interaction between alcohol dependence and extracellular cal$\operatorname{cium}\left(F_{(2,43)}=12.90, p<0.001\right)$, with alcohol's effect in $0.5 \mathrm{~mm}$ calcium aCSF increased in CIE versus naive rats cells $(p<0.001$ by Bonferroni post hoc test). There was also a significant per se effect of $5 \mathrm{~mm}$ calcium aCSF (vs $2 \mathrm{~mm}$ ) on sIPSC frequencies in naive rats $\left(t_{0.5 \mathrm{~mm}, \text { naive (10) }}=0.49, p=0.64\right.$ by one sample $t$ test; $t_{5 \mathrm{mM}, \text { naive }(12)}=7.09, p<0.001 ; t_{0.5 \mathrm{~mm}, \mathrm{CIE}(5)}=0.73, p=0.50$; $t_{5 \mathrm{~mm}, \mathrm{CIE}(4)}=1.61, p=0.18$; Fig. $\left.1 \mathrm{~J}\right)$. Therefore, chronic alcohol disrupted the requirement for calcium influx in acute alcohol's effects on GABA release.

\section{LTCC mechanisms of alcohol-induced CeA activity are lost with CIE}

We then used the LTCC antagonist nifedipine (10 $\mu \mathrm{M})$ to assess whether LTCC calcium influx regulates alcohol's effects. Nifedipine prevented alcohol's potentiation of sIPSC frequencies in naive rats $\left(102.0 \pm 3.6 \% ; t_{(10)}=0.55, p=0.60\right.$ by one sample $t$ test), but not in CIE rats $\left(167.6 \pm 18.9 \% ; t_{(8)}=3.57, p<0.01\right.$; Fig. $2 A$ ). This group difference (naive vs CIE: $t_{(18)}=3.75, p<$ 0.01 by unpaired two-tailed $t$ test) suggests that chronic alcohol exposure produces LTTC neuroadaptation. There were also significant differences in nifedipine's actions on alcohol-induced firing between the two animal groups $\left(t_{(14)}=3.82, p<0.01\right.$ by unpaired two-tailed $t$ test), as nifedipine blocked alcohol's effect in cells from naive rats that initially responded with increased firing $\left(102.3 \pm 3.6 \% ; t_{(8)}=0.64, p=0.54\right.$ by one sample $t$ test $)$, but had no effect in CIE rats $\left(143.8 \pm 11.5 \% ; t_{(6)}=3.80, p<0.01\right.$ by one sample $t$ test; Fig. $2 B$ ). In both these experiments, we verified that the cells were alcohol-responsive by first exposing a subset to alcohol alone (Fig. $2 C, D$ ). We found that the previously alcohol-responsive cells from the naive rat CeA no longer displayed alcohol enhancement of sIPSC frequencies or neuronal firing in the presence of nifedipine $\left(t_{\mathrm{SIPSC}(6)}=4.15, p<0.01\right.$ by paired two-tailed $t$ test; $\left.t_{\text {firing }(8)}=4.79, p<0.01\right)$, despite the increases produced by alcohol alone $\left(t_{\mathrm{SIPSC}, \mathrm{EtOH}(6)}=5.75, p<\right.$ 0.01 by one sample $t$ test; $t_{\text {sIPSC,wash(6) }}=0.10, p=0.92$; $t_{\text {sIPSC,nif(6) }}=0.26, p=0.81 ; t_{\mathrm{sIPSC}, \text { nif }+\mathrm{EtOH}(6)}=0.52, p=0.62$; $t_{\text {firing,EtOH(8) }}=7.12, p<0.001 ; t_{\text {firing,wash(8) }}=1.17, p=0.28$; $\left.t_{\text {firing,nif( }(8)}=0.04, p=0.97 ; t_{\text {firing,nif }+\mathrm{EtOH}(8)}=0.64, p=0.54\right)$. A second LTCC blocker, verapamil hydrochloride $(100 \mu \mathrm{M})$, mimicked nifedipine's actions in naive rats $\left(t_{(5)}=1.10, p=0.32\right.$ by one sample $t$ test), whereas $\mathrm{N}$ - and $\mathrm{P} / \mathrm{Q}$-type voltage-gated calcium 

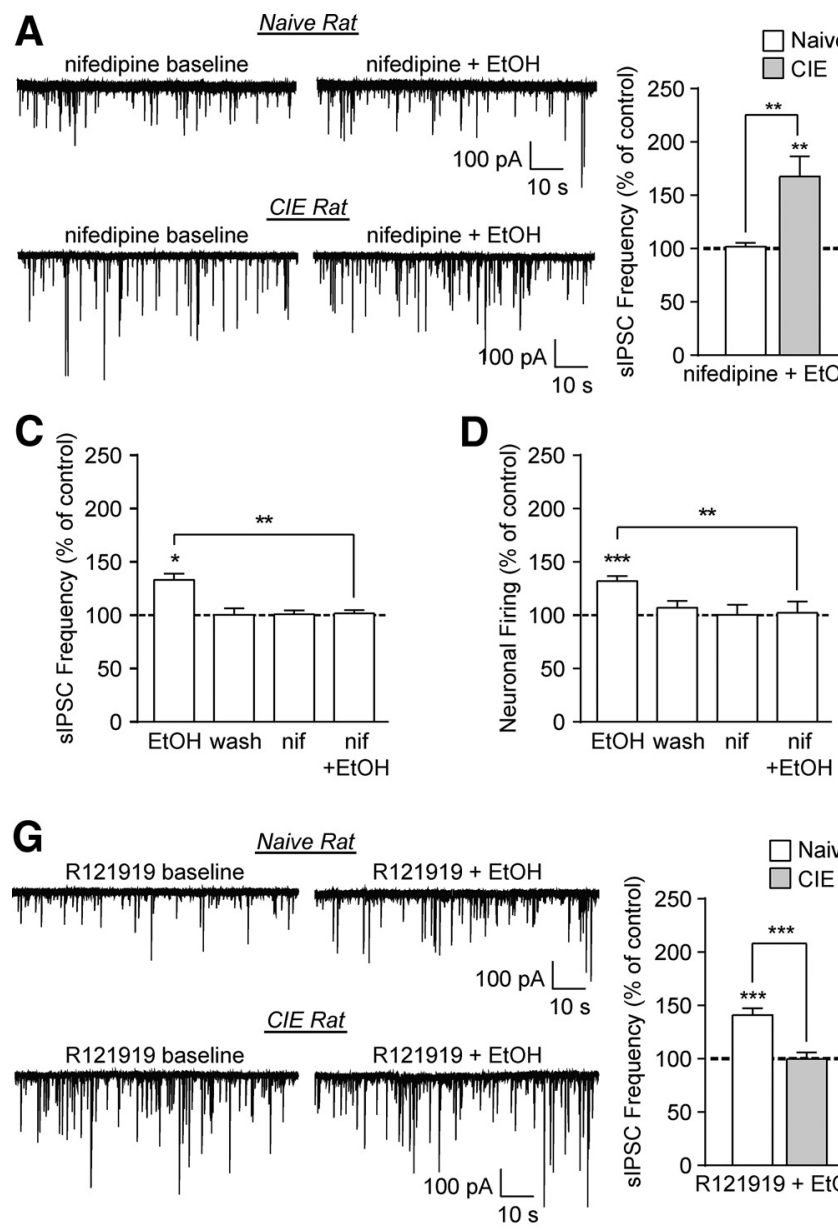
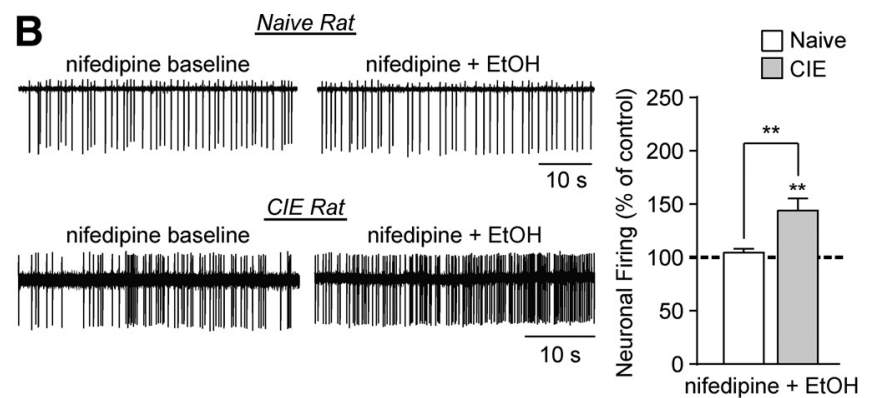

E
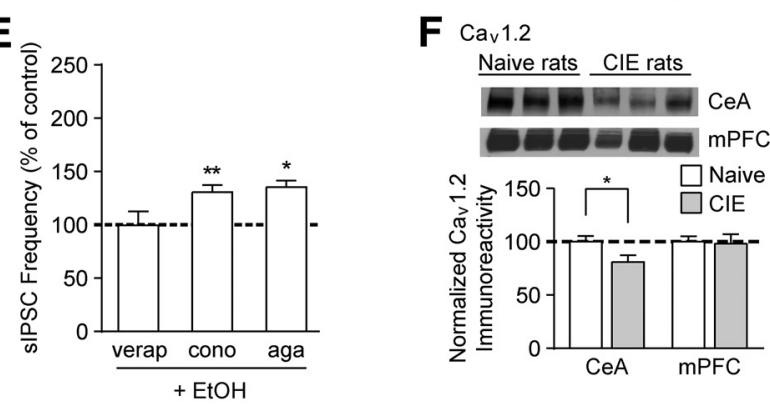

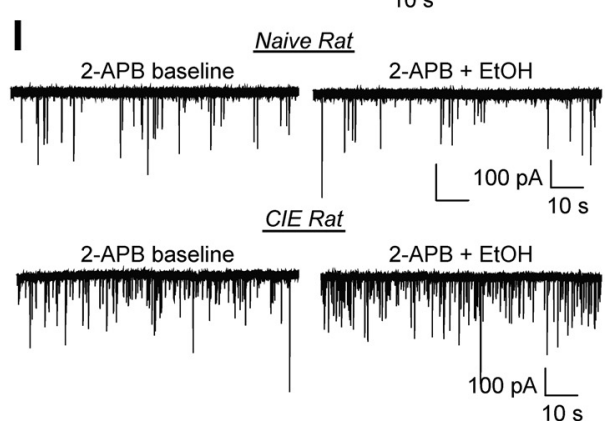

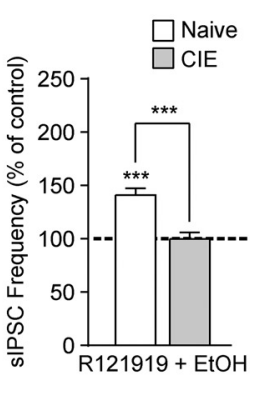

H
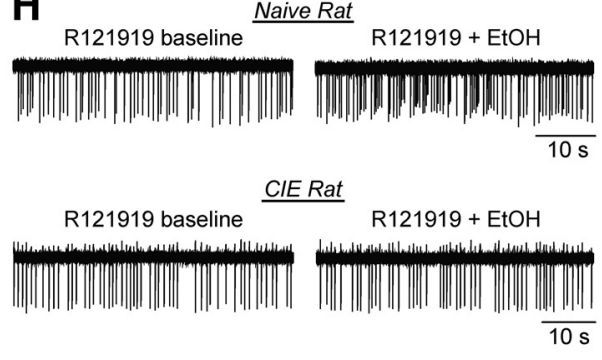

$\mathbf{J}$

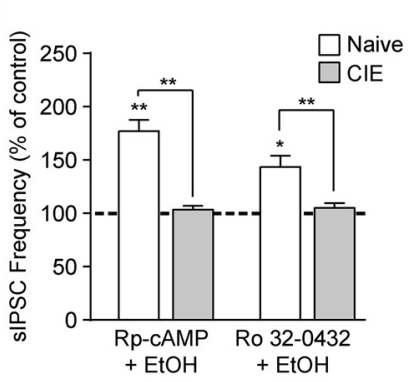

Figure 2. LTCC mechanisms of alcohol-induced (eA activity are lost in CIE rats. $A$, Nifedipine ( $10 \mu \mathrm{m})$ prevented acute alcohol's ( $44 \mathrm{~mm}$ Et0H) enhancement of sIPSC frequency in naive rats (11 cells from 7 rats), but not in CIE rats (9 cells from 6 rats). $\boldsymbol{B}$, The EtOH enhancement of neuronal firing was also blocked by nifedipine in naive rats ( 9 cells from 7 rats), but not in CIE rats ( 7 cells from 4 rats). $\boldsymbol{C}, \boldsymbol{D}$, In naive rats, previously EtOH-responsive cells no longer displayed EtOH enhancement of $(\boldsymbol{C})$ sIPSC frequency $(7$ cells from 4 rats) or (D) neuronal firing $(9$ cells from 7 rats) in the presence of nifedipine (nif). For these multistage experiments, all groups are normalized to the original pre-EtOH baseline. $\boldsymbol{E}$, EtOH's enhancement of $s$ IPSC frequency was blocked in the presence of a second LTCC blocker, verapamil (100 $\mu \mathrm{m}$ verap; 6 cells from 4 rats), but was unchanged by the N-type voltage-gated calcium channel blocker $\omega$-conotoxin GVIA (1 $\mu \mathrm{M}$ cono; 7 cells from 4 rats) or the P/Q-type voltage-gated calcium channel blocker, $\omega$-agatoxin TK ( $500 \mathrm{~nm}$ aga; 4 cells from 3 rats). $\boldsymbol{F}$, Top, Representative Western blot images of LTCC-subtype $C_{v} 1.2$ membrane abundance from the CeA and mPFC of naive and CIE rats. Bottom, Quantification revealed a significant decrease in CeA $\mathrm{Ca}_{v} 1.2$ membrane expression in (IE versus naive rats ( 6 rats were used for each experimental group). $\boldsymbol{G}, \mathrm{R} 121919(1 \mu \mathrm{M})$ prevented Et0H enhancement of sIPSC frequency in (IE rats ( 6 cells from 4 rats), but not in naive rats (9 cells from 4 rats). $\boldsymbol{H}$, The EtOH enhancement of neuronal firing was also blocked by R121919 in (IE rats (5 cells from 4 rats), but not in naive rats ( 7 cells from 4 rats). $I, I P_{3} R$ blockade ( $42 \mu \mathrm{m} 2$-APB) prevented Et0H's enhancement of the sIPSC frequency in naive rats, but not in CIE rats, whereas RyR blockade $(20 \mu \mathrm{m})$ produced the opposite result as it prevented EtOH's effects in CIE rats, but not naive rats. For these intracellular calcium experiments, $4-7$ cells from a minimum of 3 rats were used for each experimental group. J, The PKA (10 $\mu \mathrm{m}$ Rp-CAMP) and PKC antagonists (200 nм Ro 32-0432) prevented EtOH enhancement of sIPSC frequencies in CIE rats, but not naive rats. For these protein kinase experiments, 5- 6 cells from a minimum of 3 rats were used for each experimental group. All data are normalized to a pre-EtOH baseline and presented as mean \pm SEM. ${ }^{*} p<0.05,{ }^{* *} p<0.01,{ }^{* * *} p<0.001$.

channel blockade had no effect on alcohol-induced sIPSC frequencies $(1 \mu \mathrm{M} \omega$-conotoxin GVIA and $500 \mathrm{nM} \omega$-agatoxin TK, respectively; $t_{\text {cono(6) }}=4.56, p<0.01 ; t_{\mathrm{aga}(3)}=5.59, p<0.05$; Figure $2 E$ ). Therefore, alcohol's effects on CeA neurons are mediated specifically by LTCCs in naive rats, but not alcoholdependent rats.
To identify a potential mechanism for this chronic alcoholinduced disruption in LTCC signaling, we examined LTCC expression. Neuronal LTCCs are highly expressed, with $\mathrm{Ca}_{\mathrm{v}} 1.2$ (90\% of brain LTCCs; Sinnegger-Brauns et al., 2009) enriched at postsynaptic sites (Hell et al., 1993). Western blotting revealed decreased CeA Ca 1.2 membrane abundance after CIE $\left(t_{(10)}=\right.$ 
$2.26, p<0.05$ by unpaired two-tailed $t$ test; Fig. $2 F$ ). There was no difference in medial prefrontal cortex (mPFC) $\mathrm{Ca}_{\mathrm{v}} 1.2$ levels in naive versus CIE rats, despite a previous report of increased cortical LTCC expression in 1 week continuously ethanol-exposed mice (Katsura et al., 2005), indicating that our model of repeated alcohol exposures/withdrawals produces brain region-specific LTCC neuroadaptation.

Despite this disruption in LTCC signaling, we have already demonstrated that acute alcohol was able to increase CeA neuronal firing and GABA release in CIE rats (Fig. $1 E, H$ ). Previous studies report that alcohol-dependent rats exhibit heightened sensitivity to corticotropin-releasing factor type 1 receptor $\left(\mathrm{CRF}_{1}\right)$ antagonists and increased CeA CRF/CRF $\mathrm{F}_{1}$ gene expression (Roberto et al., 2010), suggesting that the CRF/CRF $\mathrm{F}_{1}$ system may compensate for LTCC disruption. Here we found that the $\mathrm{CRF}_{1}$ antagonist R121919 ( $\left.1 \mu \mathrm{M}\right)$ did not alter alcohol's potentiation of neuronal sIPSC frequencies in naive rats $(140.9 \pm 6.2 \%$; $t_{(8)}=6.65, p<0.001$ by one sample $t$ test), but prevented this effect in CIE rats $\left(99.8 \pm 6.2 \%\right.$; $t_{(5)}=0.03, p=0.97$; Fig. $\left.2 G\right)$. This group difference in naive versus CIE rats $\left(t_{(13)}=4.52, p<\right.$ 0.001 by unpaired two-tailed $t$ test) indicates that the persistent enhancement of CeA GABA release by alcohol in CIE rats is mediated by $\mathrm{CRF}_{1}$ s. There were also significant differences in R121919's actions on alcohol-induced firing between the two animal groups $\left(t_{(10)}=3.43, p<0.01\right.$ by unpaired two-tailed $t$ test), as the $\mathrm{CRF}_{1}$ antagonist blocked alcohol's facilitation of neuronal excitability in CIE rats $\left(96.7 \pm 7.1 \%\right.$; $t_{(4)}=0.46, p=0.67$ by one sample $t$ test $)$, but not in naive rats $\left(138.0 \pm 8.8 \%\right.$; $t_{(6)}=4.33$, $p<0.01$; Fig. $2 H)$. Therefore, the $\mathrm{CRF}_{1}$ mediates acute alcohol's facilitation of neuronal firing and GABA release only in alcoholdependent rats.

\section{Intracellular calcium mechanisms of alcohol-induced CeA activity}

LTCC calcium influx can trigger intracellular calcium release via $\mathrm{IP}_{3}$ Rs and RyRs (Ross, 2012), and previous work has identified a role for these mechanisms in acute alcohol's effects in other brain regions (Hirono et al., 2009; Theile et al., 2009; Qi et al., 2010; Kelm et al., 2011). Here we found that in CeA neurons of naive rats, alcohol's effect on sIPSC frequency was prevented by $\mathrm{IP}_{3} \mathrm{R}$ blockade (42 $\mu \mathrm{M} 2$-APB; $t_{(6)}=0.73, p=0.49$ by one sample $t$ test), but not by RyR blockade (20 $\mu$ M ryanodine; $t_{(4)}=3.26, p<$ 0.05; Fig. 2I). 2-APB and ryanodine did not significantly alter sIPSC amplitudes or kinetics, but 2-APB increased the sIPSC frequency in 3/7 cells and alcohol's effect was still blocked in 2/3 of these cells. These relationships were reversed with chronic alcohol exposure (naive vs CIE: $t_{2-\mathrm{APB}(9)}=2.74, p<0.05$ by unpaired two-tailed $t$ test; $t_{\text {ryanodine }(8)}=3.09, p<0.05$ by unpaired two-tailed $t$ test). Instead, the effects of alcohol on sIPSC frequencies in the CeA of CIE rats were prevented by RyR blockade $\left(t_{(4)}=\right.$ $0.04, p=0.97$ by one sample $t$ test $)$, but not $\mathrm{IP}_{3} \mathrm{R}$ blockade $\left(t_{(3)}=\right.$ $3.22, p<0.05$ by one sample $t$ test; Fig. $2 I)$. These results suggest that the switch from a LTCC- to a $\mathrm{CRF}_{1}$-based mechanism with alcohol dependence is accompanied by a shift from a role for $\mathrm{IP}_{3} \mathrm{R}$-mediated calcium-induced calcium release to the involvement of RyRs.

\section{Protein kinase pathways underlying alcohol-induced CeA activity}

LTCCs, $\mathrm{CRF}_{1} \mathrm{~s}$, and protein kinases $\mathrm{A}$ and $\mathrm{C}$ (PKA and PKC) all regulate each other and we have previously identified roles for these mechanisms in alcohol-induced action potential-independent GABA release in the CeA of naive mice (Bajo et al., 2008; Cruz et al.,
2011). Here, we found that alcohol's enhancement of action potential-dependent sIPSC frequencies was unaffected by PKA $(10 \mu \mathrm{M}$ Rp-cAMP; $t_{(5)}=4.95, p<0.01$ by one sample $t$ test) or PKC antagonism (200 nM Ro 32-0432; $\left.t_{(4)}=4.23, p<0.05\right)$ in naive rat cells, but was prevented by both antagonists after $\operatorname{CIE~}\left(t_{\mathrm{Rp} \text {-cAMP(6) }}=0.99\right.$, $p=0.36$ by one sample $t$ test; $t_{\mathrm{Ro} 32-0432(5)}=1.21, p=0.28$; Figure $2 J)$. These group differences between naive versus CIE rats $\left(t_{\mathrm{Rp}-\mathrm{cAMP}(11)}=4.39, p<0.01\right.$ by unpaired two-tailed $t$ test; $\left.t_{\mathrm{Ro} \mathrm{32-0432(9)}}=3.65, p<0.01\right)$ suggest that chronic alcohol exposure alters multiple protein kinase mechanisms so that they mediate alcohol's enhancement of action potential-dependent GABA release only in alcohol-dependent rats.

CeA LTCCs regulate alcohol intake only in nondependent rats As CeA activity regulates alcohol intake (Koob and Volkow, 2010; Gilpin et al., 2015), we assessed the effects of intra-CeA LTCC and $\mathrm{CRF}_{1}$ blockade in nondependent and alcohol-dependent rats. In nondependent rats, there was a significant effect of drug on alcohol intake $\left(F_{(2,7)}=7.85, p<0.01\right.$ by one-way ANOVA), with nifedipine $(0.125 \mu \mathrm{g} /$ side $)$ significantly reducing alcohol intake $(p<0.01$ by Newman Keuls post hoc test), whereas R121919 $(0.15 \mu \mathrm{g} / \mathrm{side})$ had no effect (Fig. $3 A)$. Water intake was unaffected $\left(F_{(2,7)}=2.6\right)$. This relationship was switched in the alcohol-dependent rats, all of whom significantly escalated their alcohol consumption during vapor exposure $\left(t_{(10)}=4.202, p<\right.$ 0.001 by paired two-tailed $t$ test; Fig. $3 B$ ). There was a significant effect of drug treatment on alcohol intake $\left(F_{(2,10)}=12.88, p<\right.$ 0.001 by one-way ANOVA), with intra-CeA R121919 significantly reducing alcohol intake in dependent rats $(p<0.001$ by Newman Keuls post hoc test), whereas nifedipine had no effect (Fig. 3B). Water intake was unaffected $\left(F_{(2,10)}=0.03\right)$. Systemic nifedipine and R121919 administration (i.p.) produced similar results (Fig. 3D-G), though a high dose of R121919 also reduced alcohol intake in nondependent rats (Fig. 3E). Collectively these data, in accordance with our cellular physiology results on the mechanisms underlying acute alcohol's effects on neuronal activity, suggest that LTCCs govern the alcohol intake of nondependent rats, while $\mathrm{CRF}_{1} \mathrm{~s}$ mediate the escalated consumption of alcohol-dependent rats.

\section{Discussion}

Here we report that alcohol dependence switches the mechanisms underlying the CeA's cellular and behavioral responses to acute alcohol. Alcohol increases CeA neuronal firing and GABA release in naive rats via LTCCs, and intra-CeA LTCC blockade reduces alcohol intake in nondependent rats (Fig. 4). Chronic alcohol exposure decreases LTCC-subtype $\mathrm{Ca}_{\mathrm{v}} 1.2$ membrane abundance and disrupts this LTCC-based mechanism. Instead, $\mathrm{CRF}_{1} \mathrm{~s}$ mediate alcohol-induced CeA activity and drive the escalated alcohol intake of alcohol-dependent rats (Fig. 4). This switch from a LTCC- to a CRF $_{1}$-based mechanism is accompanied by a shift from a role for $\mathrm{IP}_{3}$ Rs to the involvement of RyRs and PKA/PKC. Therefore, LTCCs are a critical molecular substrate in the CeA's neurobiological response to alcohol, and their neuroadaptation with repeated exposure likely contributes to the pathophysiology of alcohol use disorders.

Similar to previous studies (Chieng et al., 2006; Herman et al., 2013a; Herman and Roberto, 2016), we observed spontaneous firing with a regular discharge pattern in only a subset of recorded cells. In the absence of glutamatergic and GABAergic transmission, acute alcohol increased the spontaneous firing rate in two-thirds of these naive rat cells and in all of these CIE rat cells, indicating that alcohol's effects on neuronal firing do not stem 

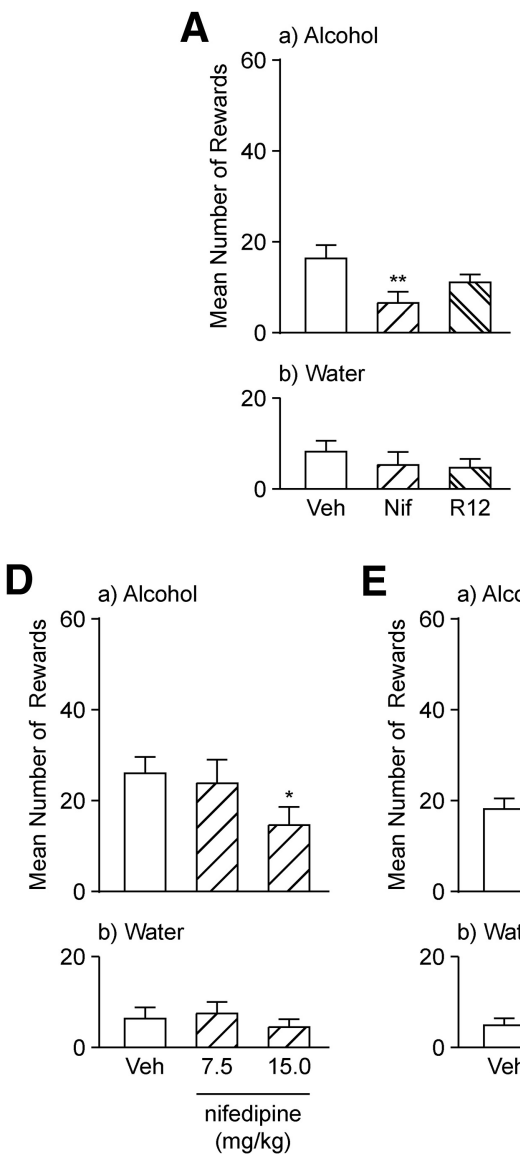

B
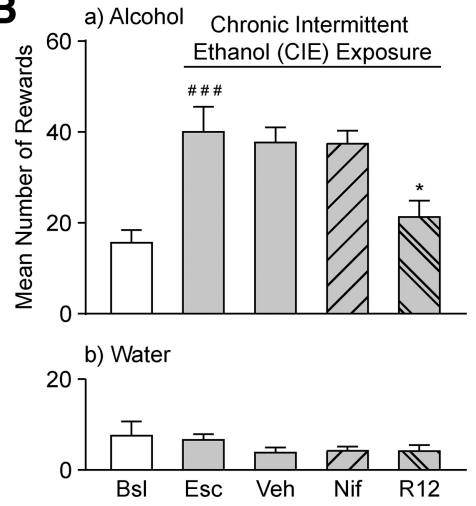

C

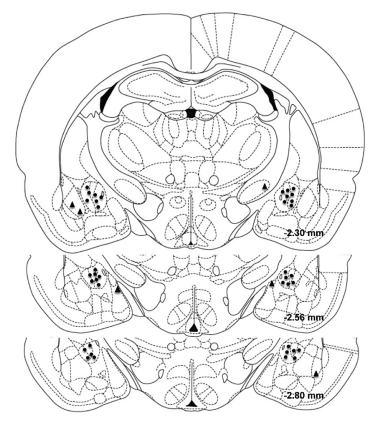

E

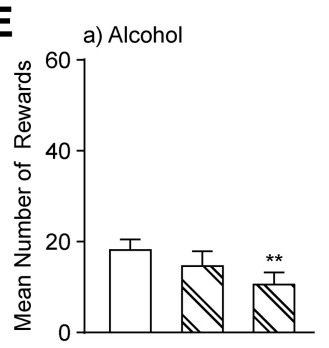

b) Water

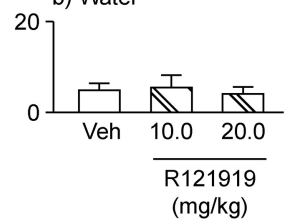

$\mathbf{F}$

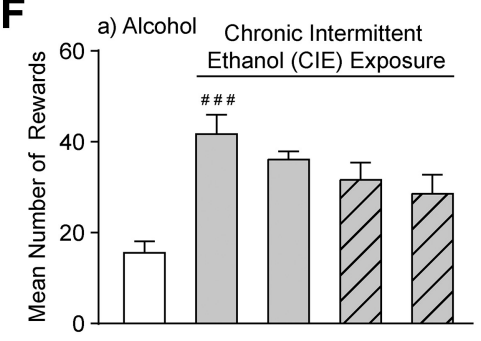

b) Water

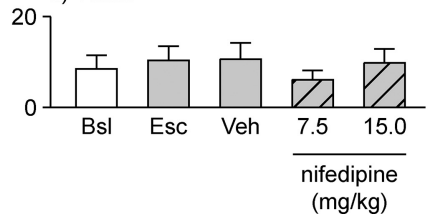

G

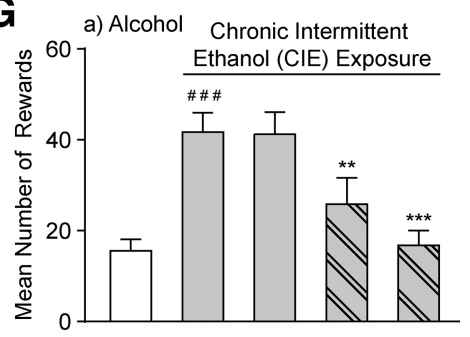

b) Water

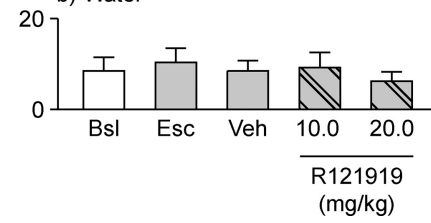

Figure 3. Intra-CeA nifedipine reduces alcohol self-administration in nondependent rats. $A$, Effect of intra-CeA nifedipine (Nif) and R121919 (R12) on alcohol self-administration in nondependent rats $(n=8)$. Data represent the number of reinforced responses for alcohol (top) or water (bottom). $\boldsymbol{B}$, Effect of intra-CeA Nif and R12 on alcohol self-administration in alcohol-dependent rats $(n=11)$ after their escalation of alcohol intake (Esc). C, Histological reconstruction showing correct (circles) and incorrect (triangles) injections into the CeA (drawing from the atlas of Paxinos and Watson, 2007). Three animals showed incorrect cannula placement and were excluded from the experiment. $\mathbf{D}-\mathbf{G}$, Effect of systemic Nif or R12 on alcohol self-administration in nondependent

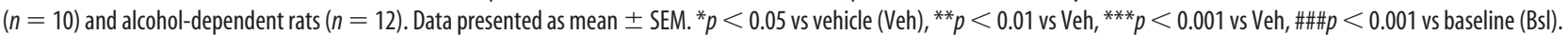

from alcohol-induced changes in neurotransmission and may be restricted to specific neuronal populations. As the CeA comprises a highly interconnected network of GABA interneurons and GABA projection neurons (Lopez de Armentia and Sah, 2004; Haubensak et al., 2010; Marek et al., 2013), alcohol enhancement of firing in a restricted neuronal population will most likely increase GABA release onto a large number of CeA neurons (as observed in this study).

\section{Alcohol activates the central amygdala via LTCCs}

We speculate that acute alcohol indirectly regulates LTTCs, rather than via a direct molecular interaction. LTCC activity can be modulated by G-protein-coupled receptors (GPCRs; Deisseroth et al., 2003; Catterall and Few, 2008) and alcohol's cellular effects can be prevented by several $\mathrm{G}_{\mathrm{s} / \mathrm{q}}$-type GPCR antagonists (Kelm et al., 2011). In particular, LTCCs mediate CRF-induced action potential firing in corticotropes (Kuryshev et al., 1996) and CRF signaling contributes to alcohol-induced evoked and action potential-independent CeA GABAergic transmission (Roberto et al., 2010; Herman et al., 2013b). Here we found that $\mathrm{CRF}_{1}$ blockade prevented alcohol-induced spontaneous action potential-dependent GABA release and neuronal firing only in CIE rats, suggesting a chronic alcohol-induced neuroadaptation in somatodendritic $\mathrm{CRF}_{1}$ s. More generally, little is known about how acute alcohol modulates CeA GPCR function, but long-term exposure alters G-protein interactions with group II metabo- tropic glutamate receptors (mGluR2/3) and serotonin receptors (5-HT1A/1B/1D; Chen and Lawrence, 2000; Kufahl et al., 2011).

Somatodendritic LTCCs can be functionally coupled to $\mathrm{IP}_{3} \mathrm{Rs}$ and RyRs on the endoplasmic reticulum (ER), so that LTCC calcium influx triggers calcium-induced calcium release (CICR; Deisseroth et al., 2003). IP ${ }_{3} \mathrm{R}$ activation also requires $\mathrm{IP}_{3}$, which is produced by phospholipase $\mathrm{C}$ (PLC) in response to $\mathrm{G}_{\mathrm{q}}$-type GPCR activation by neuromodulatory ligands like serotonin, acetylcholine and glutamate (Ross, 2012). Therefore, the $\mathrm{IP}_{3} \mathrm{R}$ is a coincidence detector for alcohol's simultaneous induction of LTCCs and PLCs. CICR can be propagated as a calcium wave along the ER and into the soma (Ross, 2012). In this way, $I_{3} R$-mediated CICR can activate calciumdependent small-conductance potassium channels, leading to a transient afterhyperpolarization that constrains action potential generation and a subsequent prolonged membrane depolarization that produces a sustained increase in neuronal firing (Hagenston et al., 2008; El-Hassar et al., 2011). A similar response to $\mathrm{IP}_{3} \mathrm{R}$-mediated CICR might drive alcohol's LTCC-dependent stimulation of CeA neuronal firing in naive rats.

LTCC calcium influx causes massive and widespread CeA activation (Hetzenauer et al., 2006) and promotes diverse processes, including gene transcription, receptor trafficking, and synaptic plasticity (Deisseroth et al., 2003; Lipscombe et al., 2004). Therefore, altered LTCC calcium signaling can profoundly impact CeA function. Our protein analysis revealed decreased $\mathrm{Ca}_{\mathrm{v}} 1.2$ membrane abundance in the CeA of CIE rats compared with naive rats, whereas 

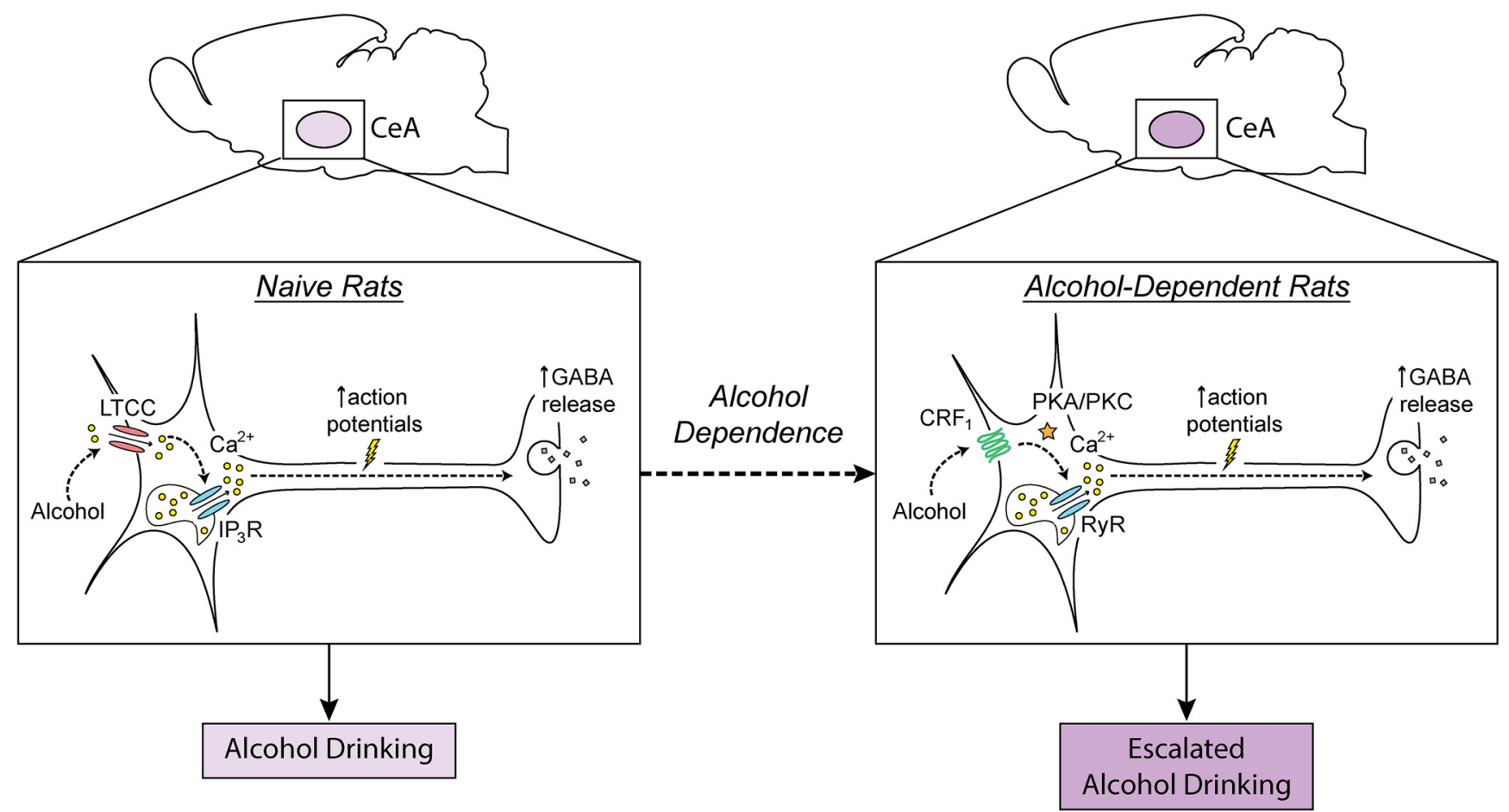

Figure 4. Schematic illustrating how the LTTC-based mechanism that mediates the CeA's neuronal response to alcohol is altered with dependence, and the behavioral outcome of this neuroadaptation. Left, In naive/nondependent rats, an LTCC-based mechanism governs: (1) alcohol's enhancement of CeA action potential-dependent GABA release and (2) CeA-driven alcohol consumption. Right, In alcohol-dependent rats, these alcohol-induced effects on CeA activity and escalated alcohol intake are mediated by a CRF 1 -based mechanism.

Uhrig et al. (2017) recently reported dynamic changes in $\mathrm{CeA} \mathrm{Ca}_{\mathrm{v}} 1.2$ gene (Cacnalc) expression during early abstinence. Notably, LTCC calcium influx can stimulate cAMP response element binding transcriptional activity (Deisseroth et al., 2003), which is associated with anxiety-like and alcohol drinking behaviors (Pandey, 2003). Genome-wide association studies have also identified specific $\mathrm{Ca}_{\mathrm{v}} 1.2$ (CACNA1C) polymorphisms as risk factors in several psychiatric disorders that exhibit amygdala dysfunction and are comorbid with alcoholism, including bipolar disease, schizophrenia and major depression (Bhat et al., 2012). In particular, the risk allele rs1006737 increased LTCC current density (Yoshimizu et al., 2015) and is associated with increased amygdala volume (Lancaster et al., 2016) and enhanced amygdala activity during emotional processing (Tesli et al., 2013).

\section{Chronic alcohol sensitizes the amygdala CRF/CRF system $_{1}$}

The chronic alcohol-induced disruption of CeA LTCC function was accompanied by a heightened regional sensitivity to the CRF/ $\mathrm{CRF}_{1}$ system, as previously described (Roberto et al., 2010). $\mathrm{CRF}_{1} \mathrm{~S}$ often signal through the adenylyl cyclase (AC)/PKA and $\mathrm{PLC} / \mathrm{PKC}$ pathways, though it is unclear whether they act on PKA and PKC independently or via crosstalk (Gutknecht et al., 2009). Here, alcohol's $\mathrm{CRF}_{1}$-mediated effects on CeA GABA release in CIE rats required PKA/PKC activity, and we have previously identified similar roles for $\mathrm{AC} 7$ and PKC $\varepsilon$ in naive mice (Bajo et al., 2008; Cruz et al., 2011; Cruz et al., 2012). CRF is a stress peptide that is cotransmitted with GABA in the CeA (Partridge et al., 2016), typically in response to neuronal burst firing (Rainnie et al., 1992; Yu and Shinnick-Gallagher, 1998), and its actions on CeA physiology are central to the interactions between negative emotion, stress and alcohol (Roberto et al., 2010; Gilpin et al., 2015). Alcohol-dependent rats exhibit increased CeA CRF/CRF gene expression (Roberto et al., 2010) and CeA-specific $\mathrm{CRF}_{1}$ blockade prevented their anxiety-like behavior (Rassnick et al., 1993). Moreover, rat amygdalar CRF peptide levels increase during early withdrawal (6-12 h; Merlo Pich et al., 1995) at time points that coincide with the acute in vitro withdrawal $(1-8 \mathrm{~h})$ of our cellular physiology studies. Notably, chronic stress increased the synaptic strength and connectivity of CeA CRF-containing neurons and these changes were associated with anxiety-like behavior (Partridge et al., 2016); similar neuroadaptation after chronic alcohol exposure would likely produce CeA overactivation, which is considered a hallmark of dependence. As such, the $\mathrm{CRF} / \mathrm{CRF}_{1}$ system is hypothesized to drive anxiety-induced drinking in human alcoholics (Koob and Volkow, 2010), and $\mathrm{CRF}_{1}(C R H R 1)$ genetic variation has been associated with heightened stress sensitivity and greater susceptibility to alcohol dependence in humans (Treutlein et al., 2006).

The CeA is an integrative hub that mediates negative emotional responses to fearful and anxiety-inducing stimuli (Gilpin et al., 2015). Its activity is central to alcohol's reinforcing actions, and its overactivation is a hallmark of dependence (Koob and Volkow, 2010; Gilpin et al., 2015). Here, we report that the CeA's cellular and behavioral responses to alcohol are generated via an LTCC-based mechanism, which is disrupted after chronic alcohol exposure. Although the CRF/CRF 1 system can superficially compensate, LTCC calcium influx is a critical regulator of cellular processes (Deisseroth et al., 2003). In particular, the absence of LTCC-driven transcriptional regulation could compound with every alcohol exposure to produce important changes in CeA cellular function. Furthermore, the CeA's heightened sensitivity to the $\mathrm{CRF} / \mathrm{CRF}_{1}$ system with alcohol dependence is associated with the escalation of alcohol intake (as seen in this study) and the kindling of anxiety-like behaviors (Koob and Volkow, 2010; Gilpin et al., 2015). It is currently unclear whether this switch in the mechanism underlying the CeA's neurobiological response to 
alcohol is a cause or consequence of the pathophysiology of dependence. Regardless, these neuroadaptations reflect the prominent role of the CeA in the escalation of drinking, and represent new potential avenues for LTCC- (Altamura et al., 1990; Banger et al., 1992; Rush and Pazzaglia, 1998; Mason et al., 2014) and $\mathrm{CRF}_{1}$-based therapeutic intervention (but see Kwako et al., 2015; Epstein et al., 2016; Schwandt et al., 2016) in the transition to alcohol dependence.

\section{References}

Alcami P, Franconville R, Llano I, Marty A (2012) Measuring the firing rate of high-resistance neurons with cell-attached recording. J Neuroscience 32:3118-3130. CrossRef Medline

Altamura AC, Regazzetti MG, Porta M (1990) Nimodipine in human alcohol withdrawal syndrome-an open study. Eur Neuropsychopharmacol 1:37-40. CrossRef Medline

Bajo M, Cruz MT, Siggins GR, Messing R, Roberto M (2008) Protein kinase C epsilon mediation of CRF- and ethanol-induced GABA release in central amygdala. Proc Natl Acad Sci U S A 105:8410-8415. CrossRef Medline

Banger M, Benkert O, Röschke J, Herth T, Hebenstreit M, Philipp M, Aldenhoff JB (1992) Nimodipine in acute alcohol withdrawal state. J Psychiatr Res 26:117-123. CrossRef Medline

Bhat S, Dao DT, Terrillion CE, Arad M, Smith RJ, Soldatov NM, Gould TD (2012) CACNA1C (Cav1.2) in the pathophysiology of psychiatric disease. Prog Neurobiol 99:1-14. CrossRef Medline

Catterall WA, Few AP (2008) Calcium channel regulation and presynaptic plasticity. Neuron 59:882-901. CrossRef Medline

Chen F, Lawrence AJ (2000) Effect of chronic ethanol and withdrawal on the mu-opioid receptor- and 5-hydroxytryptamine $(1 \mathrm{~A})$ receptor-stimulated binding of $[(35) S]$ guanosine-5'-O-(3-thio)triphosphate in the fawnhooded rat brain: a quantitative autoradiography study. J Pharmacol Exp Ther 293:159-165. Medline

Chieng BC, Christie MJ, Osborne PB (2006) Characterization of neurons in the rat central nucleus of the amygdala: cellular physiology, morphology, and opioid sensitivity. J Comp Neurol 497:910-927. CrossRef Medline

Cruz MT, Bajo M, Maragnoli ME, Tabakoff B, Siggins GR, Roberto M (2011) Type 7 adenylyl cyclase is involved in the ethanol and CRF sensitivity of GABAergic synapses in mouse central amygdala. Front Neurosci 4:207. CrossRef Medline

Cruz MT, Herman M, Kallupi M, Roberto M (2012) Nociceptin/orphanin FQ blockade of the CRF-induced GABA release in the central amygdala is enhanced after chronic ethanol treatment. Biol Psychiatry 71:666-676. CrossRef

De Beun R, Schneider R, Klein A, Lohmann A, De Vry J (1996) Effects of nimodipine and other calcium channel antagonists in alcohol-preferring AA rats. Alcohol 13:263-271. CrossRef Medline

de Guglielmo G, Crawford E, Kim S, Vendruscolo LF, Hope BT, Brennan M, Cole M, Koob GF, George O (2016) Recruitment of a neuronal ensemble in the central nucleus of the amygdala is required for alcohol dependence. J Neuroscience 36:9446-9453. CrossRef Medline

Deisseroth K, Mermelstein PG, Xia H, Tsien RW (2003) Signaling from synapse to nucleus: the logic behind the mechanisms. Curr Opin Neurobiol 13:354-365. CrossRef Medline

Edwards S, Guerrero M, Ghoneim OM, Roberts E, Koob GF (2012) Evidence that vasopressin $\mathrm{V} 1 \mathrm{~b}$ receptors mediate the transition to excessive drinking in ethanol-dependent rats. Addict Biol 17:76-85. CrossRef Medline

El-Hassar L, Hagenston AM, D’Angelo LB, Yeckel MF (2011) Metabotropic glutamate receptors regulate hippocampal CA1 pyramidal neuron excitability via $\mathrm{Ca}(2)(+)$ wave-dependent activation of SK and TRPC channels. J Physiol 589:3211-3229. CrossRef Medline

Epstein DH, Kennedy AP, Furnari M, Heilig M, Shaham Y, Phillips KA, Preston KL (2016) Effect of the CRF1-receptor antagonist pexacerfont on stress-induced eating and food craving. Psychopharmacology (Berl) 233:3921-3932. CrossRef Medline

Gilpin NW, Richardson HN, Cole M, Koob GF (2008) Vapor inhalation of alcohol in rats. Curr Protoc Neurosci Chapter 9:Unit 9.29. CrossRef Medline

Gilpin NW, Herman MA, Roberto M (2015) The central amygdala as an integrative hub for anxiety and alcohol use disorders. Biol Psychiatry 77:859-869. CrossRef Medline
Goebel-Goody SM, Davies KD, Alvestad Linger RM, Freund RK, Browning MD (2009) Phospho-regulation of synaptic and extrasynaptic $\mathrm{N}$-methyl-D-aspartate receptors in adult hippocampal slices. Neuroscience 158:1446-1459. CrossRef Medline

Gutknecht E, Van der Linden I, Van Kolen K, Verhoeven KF, Vauquelin G, Dautzenberg FM (2009) Molecular mechanisms of corticotropinreleasing factor receptor-induced calcium signaling. Mol Pharmacol 75: 648-657. CrossRef Medline

Hagenston AM, Fitzpatrick JS, Yeckel MF (2008) MGluR-mediated calcium waves that invade the soma regulate firing in layer $\mathrm{V}$ medial prefrontal cortical pyramidal neurons. Cereb Cortex 18:407-423. CrossRef Medline

Haubensak W, Kunwar PS, Cai H, Ciocchi S, Wall NR, Ponnusamy R, Biag J, Dong HW, Deisseroth K, Callaway EM, Fanselow MS, Lüthi A, Anderson DJ (2010) Genetic dissection of an amygdala microcircuit that gates conditioned fear. Nature 468:270-276. CrossRef Medline

Hell JW, Westenbroek RE, Warner C, Ahlijanian MK, Prystay W, Gilbert MM, Snutch TP, Catterall WA (1993) Identification and differential subcellular localization of the neuronal class $C$ and class D L-type calcium channel alpha 1 subunits. J Cell Biol 123:949-962. CrossRef Medline

Herman MA, Roberto M (2016) Cell-type-specific tonic GABA signaling in the rat central amygdala is selectively altered by acute and chronic ethanol. Addict Biol 21:72-86. CrossRef Medline

Herman MA, Contet C, Justice NJ, Vale W, Roberto M (2013a) Novel subunit-specific tonic GABA currents and differential effects of ethanol in the central amygdala of CRF receptor-1 reporter mice. J Neurosci 33: 3284-3298. CrossRef Medline

Herman MA, Kallupi M, Luu G, Oleata CS, Heilig M, Koob GF, Ciccocioppo R, Roberto M (2013b) Enhanced GABAergic transmission in the central nucleus of the amygdala of genetically selected Marchigian sardinian rats: alcohol and CRF effects. Neuropharmacology 67:337-348. CrossRef Medline

Hetzenauer A, Sinnegger-Brauns MJ, Striessnig J, Singewald N (2006) Brain activation pattern induced by stimulation of L-type $\mathrm{Ca} 2+$-channels: contribution of $\mathrm{Ca}(\mathrm{V}) 1.3$ and $\mathrm{Ca}(\mathrm{V}) 1.2$ isoforms. Neuroscience 139:10051015. CrossRef Medline

Hirono M, Yamada M, Obata K (2009) Ethanol enhances both action potential-dependent and action potential-independent GABAergic transmission onto cerebellar Purkinje cells. Neuropharmacology 57:109-120. CrossRef Medline

Katsura M, Torigoe F, Hayashida S, Honda T, Tsujimura A, Ohkuma S (2005) Ethanol physical dependence is accompanied by up-regulated expression of L-type high voltage-gated calcium channel alphal subunits in mouse brain. Brain Res 1039:211-215. CrossRef Medline

Kelm MK, Criswell HE, Breese GR (2011) Ethanol-enhanced GABA release: a focus on G-protein-coupled receptors. Brain Res Rev 65:113-123. CrossRef Medline

Koob GF, Volkow ND (2010) Neurocircuitry of addiction. Neuropsychopharmacology 35:217-238. CrossRef Medline

Kufahl PR, Martin-Fardon R, Weiss F (2011) Enhanced sensitivity to attenuation of conditioned reinstatement by the mGluR 2/3 agonist LY379268 and increased functional activity of mGluR $2 / 3$ in rats with a history of ethanol dependence. Neuropsychopharmacology 36: 2762-2773. CrossRef Medline

Kuryshev YA, Childs GV, Ritchie AK (1996) Corticotropin-releasing hormone stimulates $\mathrm{Ca} 2+$ entry through L- and P-type $\mathrm{Ca} 2+$ channels in rat corticotropes. Endocrinology 137:2269-2277. CrossRef Medline

Kwako LE, Spagnolo PA, Schwandt ML, Thorsell A, George DT, Momenan R, Rio DE, Huestis M, Anizan S, Concheiro M, Sinha R, Heilig M (2015) The corticotropin releasing hormone-1 (CRH1) receptor antagonist pexacerfont in alcohol dependence: a randomized controlled experimental medicine study. Neuropsychopharmacology 40:1053-1063. CrossRef Medline

Lancaster TM, Foley S, Tansey KE, Linden DE, Caseras X (2016) CACNA1C risk variant is associated with increased amygdala volume. Eur Arch Psychiatry Clin Neurosci 266:269-275. CrossRef Medline

Lee AM, Wu DF, Dadgar J, Wang D, McMahon T, Messing RO (2015) PKCepsilon phosphorylates alpha4beta2 nicotinic ACh receptors and promotes recovery from desensitization. Br J Pharmacol 172:4430-4441. CrossRef Medline

Lipscombe D, Helton TD, Xu W (2004) L-type calcium channels: the low down. J Neurophysiol 92:2633-2641. CrossRef Medline

Lopez de Armentia M, Sah P (2004) Firing properties and connectivity of 
neurons in the rat lateral central nucleus of the amygdala. J Neurophysiol 92:1285-1294. CrossRef Medline

Marek R, Strobel C, Bredy TW, Sah P (2013) The amygdala and medial prefrontal cortex: partners in the fear circuit. J Physiol 591:2381-2391. CrossRef CrossRef

Mason BJ, Quello S, Goodell V, Shadan F, Kyle M, Begovic A (2014) Gabapentin treatment for alcohol dependence: a randomized clinical trial. JAMA Intern Med 174:70-77. CrossRef Medline

Merlo Pich E, Lorang M, Yeganeh M, Rodriguez de Fonseca F, Raber J, Koob GF, Weiss F (1995) Increase of extracellular corticotropin-releasing factor-like immunoreactivity levels in the amygdala of awake rats during restraint stress and ethanol withdrawal as measured by microdialysis. J Neurosci 15:5439-5447. Medline

Murase K, Ryu PD, Randic M (1989) Excitatory and inhibitory amino acids and peptide-induced responses in acutely isolated rat spinal dorsal horn neurons. Neurosci Lett 103:56-63. CrossRef Medline

O’Dell LE, Roberts AJ, Smith RT, Koob GF (2004) Enhanced alcohol selfadministration after intermittent versus continuous alcohol vapor exposure. Alcohol Clin Exp Res 28:1676-1682. CrossRef Medline

Otis TS, De Koninck Y, Mody I (1994) Lasting potentiation of inhibition is associated with an increased number of gamma-aminobutyric acid type $\mathrm{A}$ receptors activated during miniature inhibitory postsynaptic currents. Proc Natl Acad Sci U S A 91:7698-7702. CrossRef Medline

Pandey SC (2003) Anxiety and alcohol abuse disorders: a common role for CREB and its target, the neuropeptide Y gene. Trends Pharmacol Sci 24:456-460. CrossRef Medline

Partridge JG, Forcelli PA, Luo R, Cashdan JM, Schulkin J, Valentino RJ, Vicini S (2016) Stress increases GABAergic neurotransmission in CRF neurons of the central amygdala and bed nucleus stria terminalis. Neuropharmacology 107:239-250. CrossRef Medline

Paxinos G, Watson C (2007) The rat brain in stereotaxic coordinates. San Diego: Elsevier Academic.

Qi SH, Liu Y, Hao LY, Guan QH, Gu YH, Zhang J, Yan H, Wang M, Zhang GY (2010) Neuroprotection of ethanol against ischemia/reperfusioninduced brain injury through decreasing c-Jun $\mathrm{N}$-terminal kinase 3 (JNK3) activation by enhancing GABA release. Neuroscience 167:11251137. CrossRef Medline

Rainnie DG, Fernhout BJ, Shinnick-Gallagher P (1992) Differential actions of corticotropin releasing factor on basolateral and central amygdaloid neurones, in vitro. J Pharmacol Exp Ther 263:846-858. Medline

Rassnick S, Heinrichs SC, Britton KT, Koob GF (1993) Microinjection of a corticotropin-releasing factor antagonist into the central nucleus of the amygdala reverses anxiogenic-like effects of ethanol withdrawal. Brain Res 605:25-32. CrossRef Medline

Rimondini R, Sommer W, Heilig M (2003) A temporal threshold for induction of persistent alcohol preference: behavioral evidence in a rat model of intermittent intoxication. J Studies Alcohol 64:445-449. CrossRef Medline

Roberto M, Madamba SG, Stouffer DG, Parsons LH, Siggins GR (2004) Increased GABA release in the central amygdala of ethanol-dependent rats. J Neurosci 24:10159-10166. CrossRef Medline

Roberto M, Gilpin NW, O’Dell LE, Cruz MT, Morse AC, Siggins GR, Koob GF (2008) Cellular and behavioral interactions of gabapentin with alcohol dependence. J Neurosci 28:5762-5771. CrossRef Medline

Roberto M, Cruz MT, Gilpin NW, Sabino V, Schweitzer P, Bajo M, Cottone P, Madamba SG, Stouffer DG, Zorrilla EP, Koob GF, Siggins GR, Parsons LH (2010) Corticotropin releasing factor-induced amygdala gammaaminobutyric acid release plays a key role in alcohol dependence. Biol Psychiatry 67:831-839. CrossRef Medline

Roberts AJ, Heyser CJ, Cole M, Griffin P, Koob GF (2000) Excessive ethanol drinking following a history of dependence: animal model of allostasis. Neuropsychopharmacology 22:581-594. CrossRef Medline

Ross WN (2012) Understanding calcium waves and sparks in central neurons. Nat Rev Neurosci 13:157-168. CrossRef Medline

Rush CR, Pazzaglia PJ (1998) Pretreatment with isradipine, a calciumchannel blocker, does not attenuate the acute behavioral effects of ethanol in humans. Alcohol Clinl Exp Res 22:539-547. CrossRef
Schulteis G, Markou A, Cole M, Koob GF (1995) Decreased brain reward produced by ethanol withdrawal. Proc Natl Acad Sci U S A 92:58805884. CrossRef Medline

Schwandt ML, Cortes CR, Kwako LE, George DT, Momenan R, Sinha R, Grigoriadis DE, Pich EM, Leggio L, Heilig M (2016) The CRF1 antagonist verucerfont in anxious alcohol-dependent women: translation of neuroendocrine, but not of anti-craving effects. Neuropsychopharmacology 41:2818-2829. CrossRef Medline

Sills GJ (2006) The mechanisms of action of gabapentin and pregabalin. Curr Opin Pharmacol 6:108-113. CrossRef Medline

Sinnegger-Brauns MJ, Huber IG, Koschak A, Wild C, Obermair GJ, Einzinger U, Hoda JC, Sartori SB, Striessnig J (2009) Expression and 1,4-dihydropyridine-binding properties of brain L-type calcium channel isoforms. Mol Pharmacol 75:407-414. CrossRef Medline

Sommer WH, Rimondini R, Marquitz M, Lidström J, Siems WE, Bader M, Heilig M (2007) Plasticity and impact of the central renin-angiotensin system during development of ethanol dependence. J Mol Med 85:10891097. CrossRef Medline

Tesli M, Skatun KC, Ousdal OT, Brown AA, Thoresen C, Agartz I, Melle I, Djurovic S, Jensen J, Andreassen OA (2013) CACNA1C risk variant and amygdala activity in bipolar disorder, schizophrenia and healthy controls. PloS One 8:e56970. CrossRef Medline

Theile JW, Morikawa H, Gonzales RA, Morrisett RA (2009) Role of 5-hydroxytryptamine $2 \mathrm{C}$ receptors in $\mathrm{Ca} 2+$-dependent ethanol potentiation of GABA release onto ventral tegmental area dopamine neurons. J Pharmacol Exp Ther 329:625-633. CrossRef Medline

Townshend JM, Duka T (2003) Mixed emotions: alcoholics' impairments in the recognition of specific emotional facial expressions. Neuropsychologia 41:773-782. CrossRef Medline

Treutlein J, Kissling C, Frank J, Wiemann S, Dong L, Depner M, Saam C, Lascorz J, Soyka M, Preuss UW, Rujescu D, Skowronek MH, Rietschel M, Spanagel R, Heinz A, Laucht M, Mann K, Schumann G (2006) Genetic association of the human corticotropin releasing hormone receptor 1 (CRHR1) with binge drinking and alcohol intake patterns in two independent samples. Mol Psychiatry 11:594-602. CrossRef Medline

Uhrig S, Vandael D, Marcantoni A, Dedic N, Bilbao A, Vogt MA, Hirth N, Broccoli L, Bernardi RE, Schönig K, Gass P, Bartsch D, Spanagel R, Deussing JM, Sommer WH, Carbone E, Hansson AC (2017) Differential roles for L-type calcium channel subtypes in alcohol dependence. Neuropsychopharmacology 42:1058-1069. CrossRef Medline

Valdez GR, Roberts AJ, Chan K, Davis H, Brennan M, Zorrilla EP, Koob GF (2002) Increased ethanol self-administration and anxiety-like behavior during acute ethanol withdrawal and protracted abstinence: regulation by corticotropin-releasing factor. Alcohol Clin Exp Res 26:1494-1501. CrossRef Medline

Varodayan FP, Soni N, Bajo M, Luu G, Madamba SG, Schweitzer P, Parsons LH, Roberto M (2016) Chronic ethanol exposure decreases CB receptor function at GABAergic synapses in the rat central amygdala. Addict Biol 21:788-801. CrossRef Medline

Walter HJ, Messing RO (1999) Regulation of neuronal voltage-gated calcium channels by ethanol. Neurochem Int 35:95-101. CrossRef Medline

Watson WP, Little HJ (2002) Selectivity of the protective effects of dihydropyridine calcium channel antagonists against the ethanol withdrawal syndrome. Brain Res 930:111-122. CrossRef Medline

Welinder C, Ekblad L (2011) Coomassie staining as loading control in Western blot analysis. J Proteome Res 10:1416-1419. CrossRef Medline

Yoshimizu T, Pan JQ, Mungenast AE, Madison JM, Su S, Ketterman J, Ongur D, McPhie D, Cohen B, Perlis R, Tsai LH (2015) Functional implications of a psychiatric risk variant within CACNA1C in induced human neurons. Mol Psychiatry 20:162-169. CrossRef Medline

Yu B, Shinnick-Gallagher P (1998) Corticotropin-releasing factor increases dihydropyridine- and neurotoxin-resistant calcium currents in neurons of the central amygdala. J Pharmacol Exp Ther 284:170-179. Medline

Zhao Y, Weiss F, Zorrilla EP (2007) Remission and resurgence of anxietylike behavior across protracted withdrawal stages in ethanol-dependent rats. Alcohol Clin Exp Res 31:1505-1515. CrossRef Medline 